\title{
Westward bottom currents along the margin of the South Shetland Island Arc
}

\author{
W. D. Nowlin, Jr* and WALTER ZenK†
}

(Received 16 January 1987; in revised form 7 August 1987; accepted 19 August 1987)

\begin{abstract}
Existing information is synthesized and new data presented to describe the flow of near-bottom water from the Weddell Sea into the Scotia Sea and westward through Drake Passage along the continental slope. The water characteristics and currents along the northern margins of the South Sandwich Island Arc are examined. Long-term current measurements in the bottom waters at locations over the outer shelf and slope and along the continental rise show persistent flow from Atlantic to Pacific along isobaths at speeds of $10-20 \mathrm{~cm} \mathrm{~s}^{-1}$. Three sources for the waters in these currents are identified and discussed. At the deepest levels, Weddell Sea Deep Water enters the Scotia Sea near $40^{\circ} \mathrm{W}$ through a depression in the South Scotia Arc and then flows westward, constrained by the bottom topography. This cold, fresh, oxygenated bottom water then flows west to enter Drake Passage via a gap in the Shackleton Fracture Zone at the base of the continental slope northwest of Elephant Island. Mid-depth waters may flow from the Weddell Sea to the Scotia Sea through the Powell Basin (sill depth approximately $2000 \mathrm{~m}$ ) located west of South Orkney Island near $48^{\circ} \mathrm{W}$. The westward flowing waters along the shelf and upper continental slope, which are denser than those immediately offshore, may be a continuation of the Polar Slope Current from the Weddell Sea or may be derived principally by convection from the shelves of the South Sandwich Island Arc. A vertical section north of Elephant Island shows downslope convection off the shelf, analogous to that observed at many locations around Antarctica.
\end{abstract}

\section{INTRODUCTION}

DURING the past decade much attention has been focused on the flow of the Antarctic Circumpolar Current from Pacific to Atlantic Ocean through Drake Passage. However, there is also flow from the Weddell Sea into the Scotia Sea and westward through Drake Passage along the continental slope north of the South Shetland Islands. Our intention is to synthesize existing information and present new data describing that flow, and to show the similarity between thermohaline convection off the shelves of Antarctica and that off the shelf of the South Shetland Islands. Bathymetry and useful place names for the area of interest are shown in Fig. 1.

There is strong geological evidence for a northward boundary current along the western margin of the Weddell Sea. Hollister and EldER (1969) compiled visible evidence (including ripple marks, murky water and oriented photographs) for the existence of this current from at least 2000 to over $4000 \mathrm{~m}$ along the bottom (Fig. 2). At some locations evidence was found at bottom depths less than $2000 \mathrm{~m}$. HoLlisTer and ELDER suggested that this flow extends eastward along the southern margin of the South Sandwich Island Arc and then northward over the South Sandwich Trench into the

* Department of Oceanography, Texas A\&M University, College Station, TX 77843, U.S.A.

† Institut für Meereskunde an der Universität Kiel, 2000 Düsternbrooker Weg, D-2300 Kiel, F.R.G. 


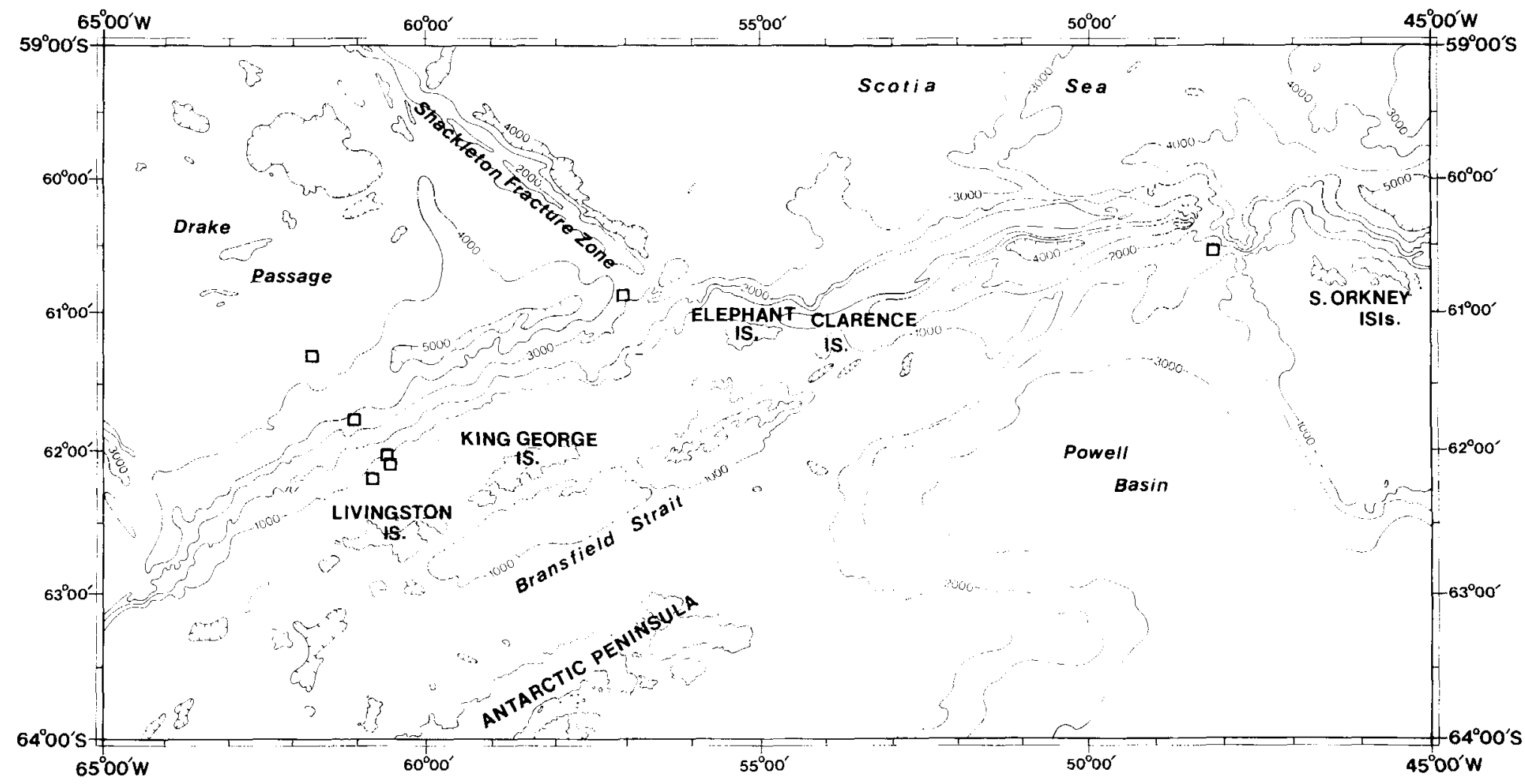

Fig. 1. Bathymetric chart of the study area adapted from General Bathymetric Chart of the Oceans (GEBCO No. 5.16). Depths in the southern Drake Passage are taken from a compilation of data by T. Whitworth III. Indicated by squares are the locations of 7 moorings from which time series are used in this study. 


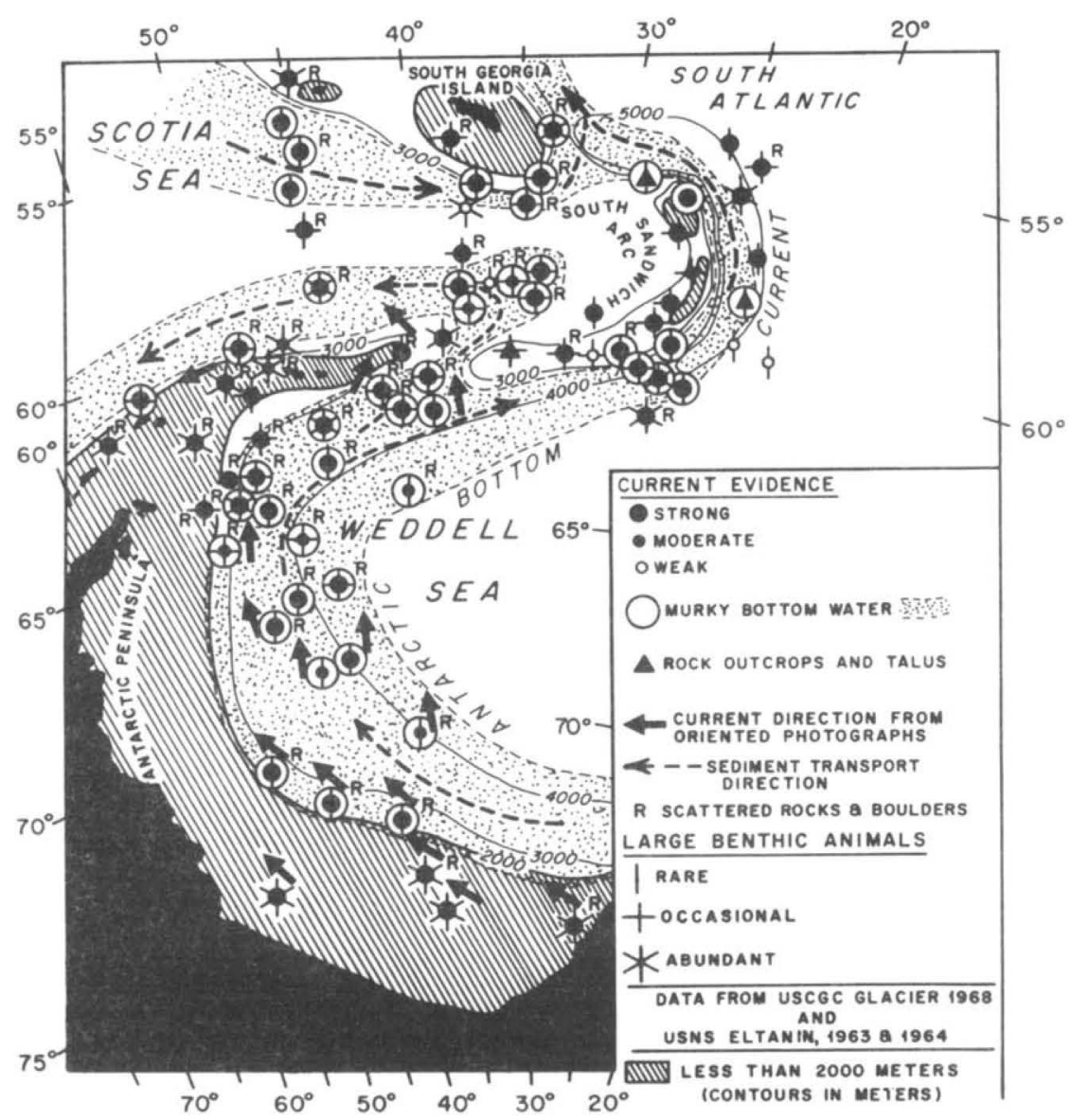

Fig. 2. Geological evidence for a deep contour current in the Weddell Sea with a branch into the Scotia Sea and westward through Drake Passage (from HollisTER and ELDER, 1969).

Georgia Basin and South Atlantic. Another branch was inferred to flow northward through a gap in the South Sandwich Island Arc near $40^{\circ} \mathrm{W}$ and then westward along the margin into the Pacific Ocean.

In another paper, Hollister and HeEzen (1967) inferred that the bottom flow continues westward through Drake Passage along the continental margin of Antarctica to at least $120^{\circ} \mathrm{W}$. In the Scotia Sea, they showed westward bottom currents from oriented photographs near $60.5^{\circ} \mathrm{S}$ between 47 and $49^{\circ} \mathrm{W}$, just northwest of the maximum sill depth between the Powell Basin and Scotia Sea (Fig. 1). Near our current meter mooring northwest of Elephant Island, they reported a very strong bottom current as evidenced by ripple marks.

Westward surface flow at the northern end of the Antarctic Peninsula was noted by DeAcon (1933, p. 187), and westward flow in the Bransfield Strait has recently been confirmed by the tracks of two surface drifters (nos 54611 and 54612) launched as part of the First GARP (Global Atmospheric Research Programme) Global Experiment. Other authors also have indicated westward surface currents in the south of Drake Passage (e.g. 
DiETRICH et al., 1975), who show (their plate 6) a westward surface current vector north of the Antarctic Peninsula. (Whether such representations are added simply to provide some circumpolar continuity to the Polar Current or because of specific knowledge is unknown.)

Westward flow north of Livingston Island was reported by WHITwORTH et al. (1982). They referenced relative geostrophic shears from hydrographic observations in January 1979, April 1979 and January 1980 to direct speed measurements to obtain three vertical sections across Drake Passage of net geostrophic speed and three estimates of net volume transport of the Antarctic Circumpolar Current. Each of the speed sections shows a westward current at the sea surface off the seaward edge of the continental shelf and within the near-bottom waters above the continental slope to the greatest depths sampled (approximately $3600 \mathrm{~m}$ ).

In Fig. 3 we show for the southernmost $300 \mathrm{~km}$ of Drake Passage the distributions of net geostrophic speed normal to the sections of WHITwORTH et al. (1982). These have been modified to include the 500-m current speeds from mooring SS500 (the southernmost current values shown), and isotachs have been smoothly extrapolated to the bottom. In all three sections westward flow is seen adjacent to the continental slope and rise extending from the shelf to the greatest depths. Whiтworth et al. (1982) noted the implication for steadiness of this westward flow. Speeds range up to just $<10 \mathrm{~cm} \mathrm{~s}^{-1}$, with a spatial average for the three sections of approximately $5 \mathrm{~cm} \mathrm{~s}^{-1}$. Based on areas and speeds from these sections we estimate westward transport of approximately $1.4 \times$ $10^{6} \mathrm{~m}^{3} \mathrm{~s}^{-1}$ for January 1979 and 1980 and $3.2 \times 10^{6} \mathrm{~m}^{3} \mathrm{~s}^{-1}$ for April 1979 .

Observations of the thermohaline structure in vertical section over the shelf break and slope have been reported from many locations around Antarctica. GILL (1973) discussed the circulation in and through such sections in his study of circulation and bottom water production in the Weddell Sea. In his review of shelf convection, KILL WORTH (1983) cited observations from the Ross Sea near $170^{\circ} \mathrm{W}$ (JACOBS et al., 1970), off Wilkes Land near $155^{\circ} \mathrm{E}$ (CARMaCK and Killworth, 1978), off the Adelie Coast near $145^{\circ} \mathrm{E}$ (Gordon and TCHERNIA, 1972), off Enderby Land near $60^{\circ}$ (JACOBS and GeORGI, 1977), and within the Weddell Sea near $29^{\circ}$ and $40^{\circ} \mathrm{W}$ (Foster and CARMACK, 1976). Observations in vertical sections near $36^{\circ} \mathrm{W}$ were reported by FoldviK et al. (1985).

In a section crossing the shelf break near $40^{\circ} \mathrm{W}$ in the Weddell Sea, Foster and CARMACK (1976) showed (Fig. 4) relatively cold (and fresh) water along the bottom on the shelf and over the slope. At least two features are characteristic of other Antarctic shelf-slope sections (except that in the Ross Sea the denser shelf and bottom slope water is relatively cold and salty). First, there is an extension of dense water from the outer shelf down the upper slope. In some cases relatively dense water is found along the bottom to the base of the slope. Second, above the slope the density field slopes upward toward the south. The slope of isopycnals is larger near the bottom than in the overlying water column.

These distributions have several implications. It may be concluded that denser water has convected downward along the slope-sometimes to its base. The baroclinic flow along the bottom is westward relative to upper layers. Thus, the deeper dense water found in a section may have begun its vertical convection far to the "east" of the observations, i.e. upstream.

We have assembled a data set which shows a similar thermohaline structure along the shelf break north of the South Shetland Islands. Moreover, with these data we can: show 

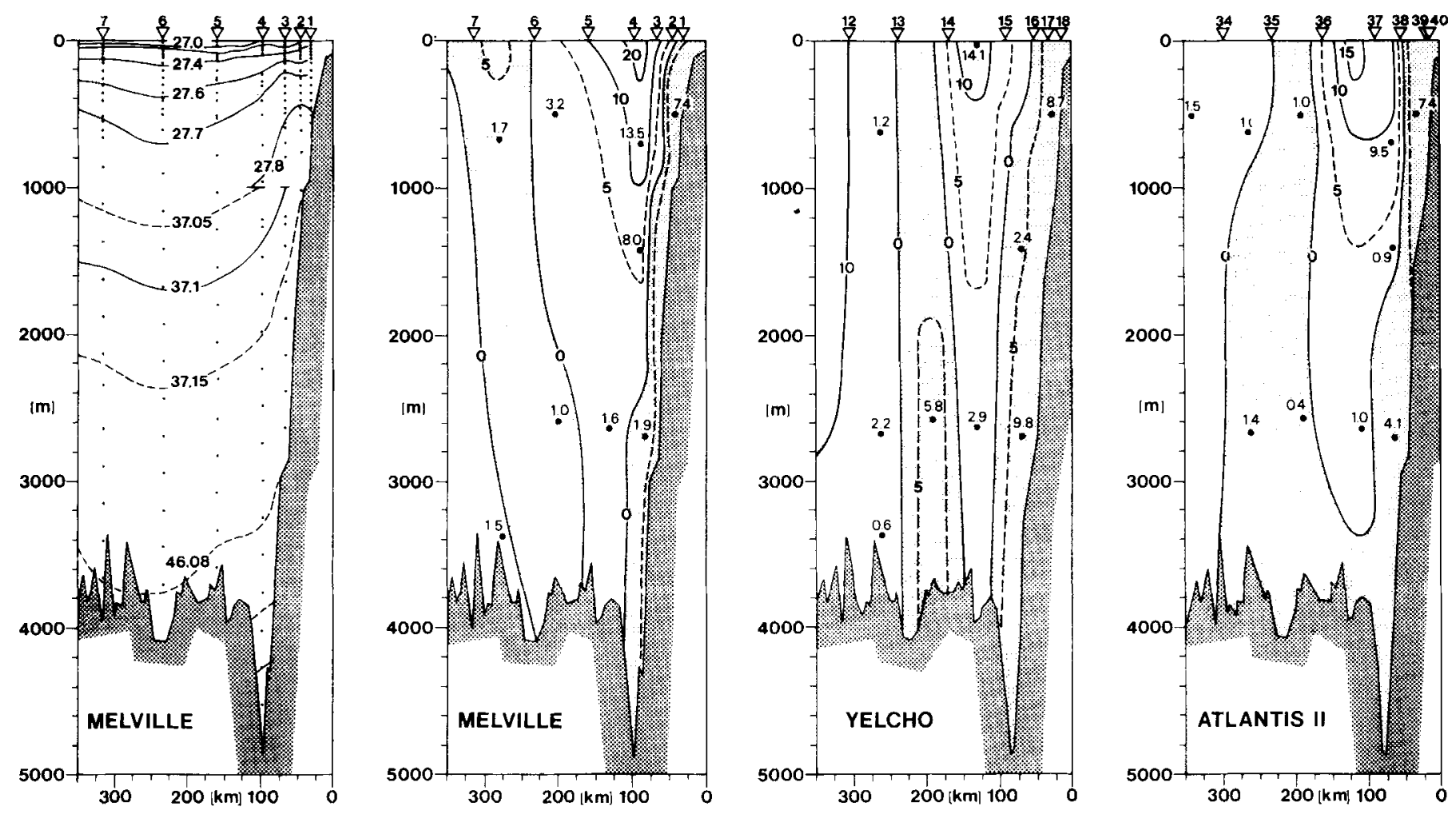

Fig. 3. Potential density anomaly $\left(\sigma_{0}, \sigma_{2}\right.$ and $\left.\sigma_{4}\right)$ and net geostrophic, through-passage speed in vertical section (adapted from WHITWORTH et al, 1982). The section line extends through the three outermost mooring locations shown off Livingston Island in Fig. 1. Melville, Yelcho and Atlantis II sections are from January 1979, April 1979 and January 1980, respectively. Current meter reference speeds are given (cm $\mathrm{s}^{-1}$ ) and typical hydrographic sample positions are shown for the Melville section. 


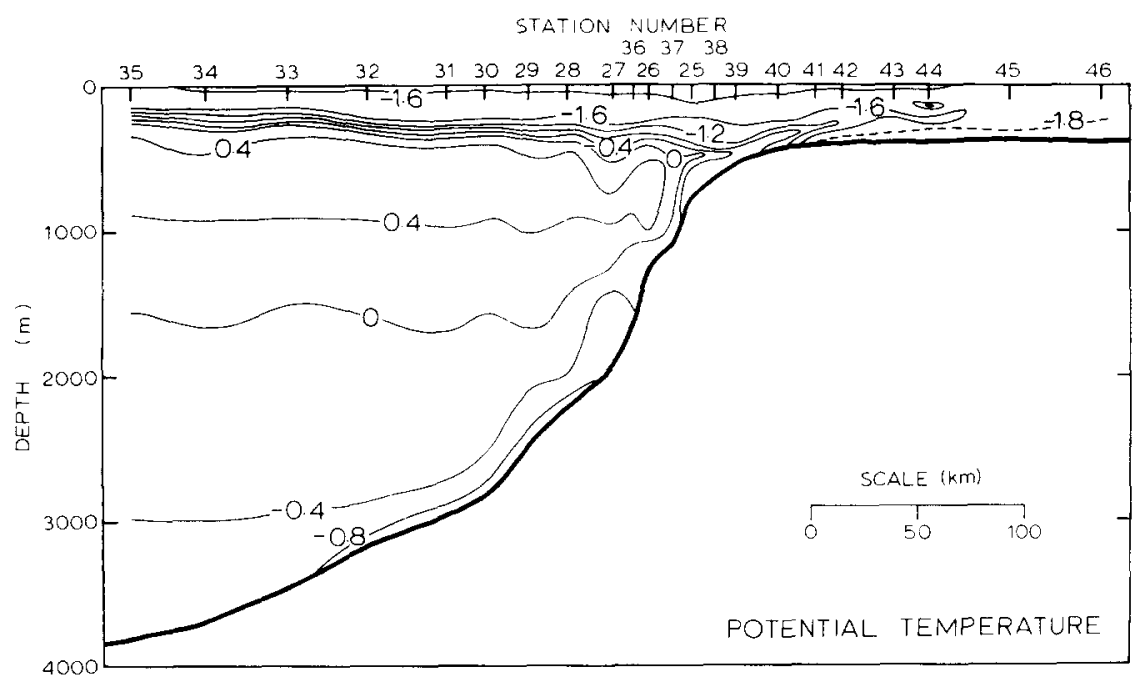

Fig. 4. Potential temperature $\left({ }^{\circ} \mathrm{C}\right)$ observed over the shelf break and slope near $40^{\circ} \mathrm{W}$ in the Weddell Sea (from Foster and CARMACK, 1976).

that near-bottom flow directions along the continental margin are persistently westward; describe the values of characteristics (from temperature to fluorocarbon-11) within this slope current; trace the routes of the near-bottom flow from the Weddell Sea through the Scotia Sea and Drake Passage; and describe selected kinematic properties of this flow at several locations.

In Section 2 the data sets are described in chronological order of their acquisition. The water mass characteristics in vertical sections and bottom property distributions, which indicate abyssal current paths, are given in Section 3. The final sections include our analyses of the time series measurements as they pertain to the westward slope current and a brief discussion of the implications of this westward flow.

\section{THE DATA SETS}

The principal data that we use are from the ISOS (International Southern Ocean Studies), from current meter deployments of the Institut für Meereskunde at Kiel (IfM), and from the Ajax expedition aboard the R.V. Knorr.

As part of ISOS, currents and temperatures were observed at five locations between January 1979 and February 1980: moorings ML-11, ST, SS1000, SS500 and bottom pressure gauge SP501 (Fig. 5). The locations, depths and recording intervals for the relevant instruments are shown in Table 1. The data from these ISOS current meter moorings were reported by Pillsbury et al. (1981) and Worley and Whitworth (1982).

ISOS current measurements in the southern Drake Passage showed persistent westward flow at bottom current meters located near the shelf edge at a depth of $500 \mathrm{~m}$ (mooring SS500) and near the bottom of the slope at a depth of $2700 \mathrm{~m}$ (mooring ST). This current was pictured by WHITWORTH $e$ t al. (1982) as a thin band extending along the continental slope north of Livingston Island (Fig. 3). This westward current was not observed by the many earlier ISOS observations made in Drake Passage because those 

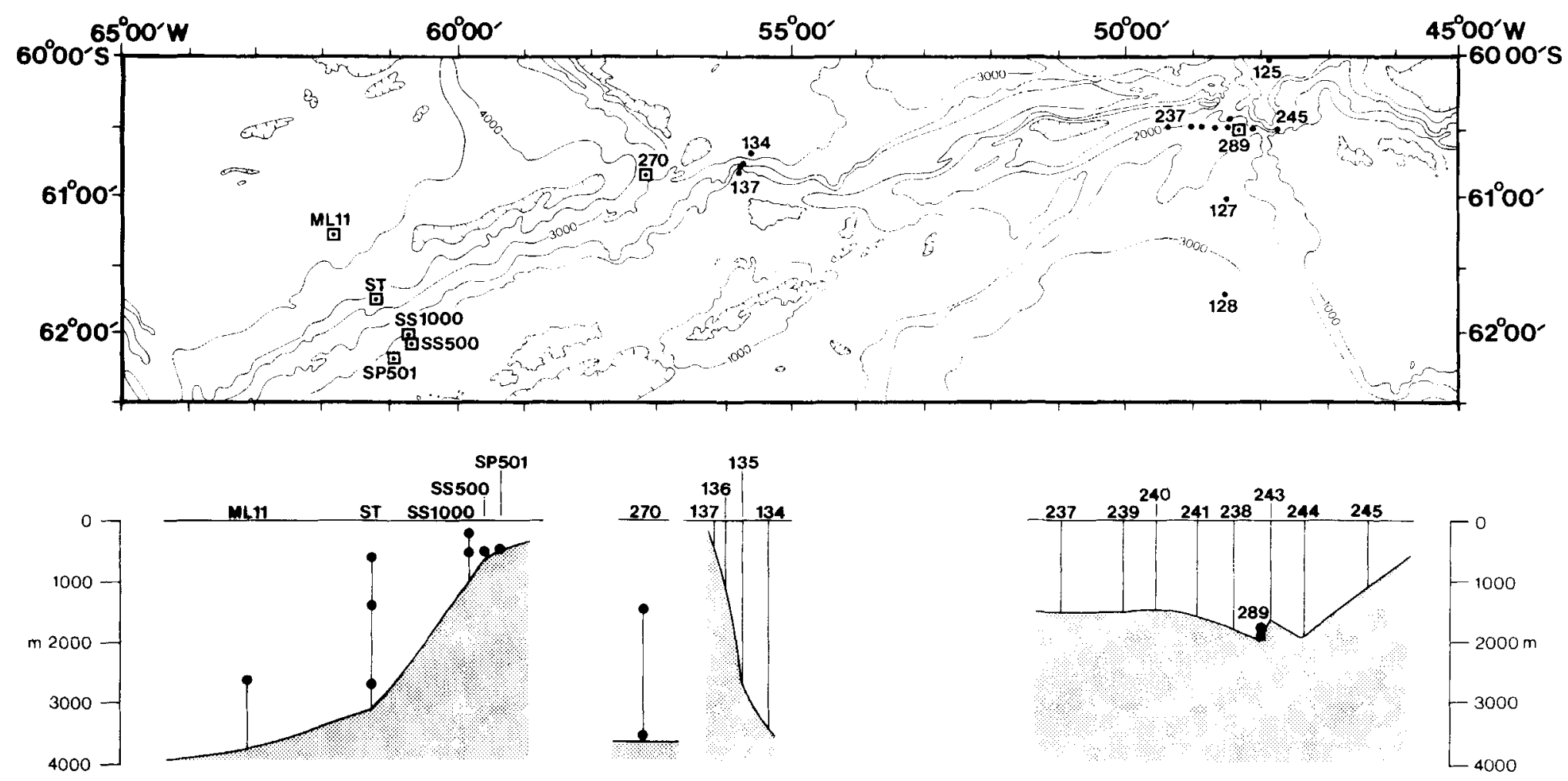

Fig. 5. Schematic showing relative locations of moorings (dots in boxes) and oceanographic stations (dots) from which data for this study were obtained. Moorings ML-11 to SP501 were in place from January 1979 to February 1980; mooring 270 from December 1980 to January 1981 ; mooring 289 from March to November 1983; Stas 237-245 were made in December 1983; and Stas 124-128 and 134-137 in February 1984. 
Table 1. Positions, depths and recording intervals of records

\begin{tabular}{llcccc}
\hline Mooring & Location & $\begin{array}{c}\text { Water } \\
\text { depth }(\mathrm{m})\end{array}$ & $\begin{array}{c}\text { Instrument } \\
\text { depth }(\mathrm{m})\end{array}$ & $\begin{array}{c}\text { Variables } \\
\text { measured }\end{array}$ & $\begin{array}{c}\text { Recording } \\
\text { interval }\end{array}$ \\
\hline ST & $61^{\circ} 48.0^{\prime} \mathrm{S}$ & 3070 & 1400 & $V, T$ & 19 Jan. 1979-14 Feb. 1980 \\
& $61^{\circ} 0.8 .5^{\prime} \mathrm{W}$ & & 2700 & $V, T$ & 19 Jan. 1979-14 Feb. 1980 \\
SS1000 & $62^{\circ} 03.6^{\prime} \mathrm{S}$ & 995 & 200 & $T$ & 23 Jan. 1979-10 Feb. 1980 \\
& $60^{\circ} 38.6^{\prime} \mathrm{W}$ & & 510 & $V, T$ & 19 Jan. 1979-20 Oct. 1979 \\
SS500 & $62^{\circ} 05.0^{\prime} \mathrm{S}$ & 600 & 500 & $V, T$ & 20 Jan. 1979-13 Feb. 1980 \\
& $60^{\circ} 34.9^{\prime} \mathrm{W}$ & & & & \\
SP501 & $62^{\circ} 11.1^{\prime} \mathrm{S}$ & 500 & 500 & $T$ & 17 Jan. 1979-15 Feb. 1980 \\
& $60^{\circ} 53.5^{\prime} \mathrm{W}$ & & & & \\
270 & $60^{\circ} 54.6^{\prime} \mathrm{S}$ & 3625 & 1489 & $V, T$ & 2 Dec. 1980-21 Jan. 1981 \\
& $57^{\circ} 06.0^{\prime} \mathrm{W}$ & & 3590 & $V, T$ & 2 Dec. 1980-21 Jan. 1981 \\
& $60^{\circ} 32.0^{\prime} \mathrm{S}$ & 1989 & 1904 & $V, T$ & 20 Mar. 1983-4 Dec. 1983 \\
& $48^{\circ} 18.8^{\prime} \mathrm{W}$ & & 1964 & $V, T$ & 20 Mar. 1983-6 Dec. 1983 \\
\hline
\end{tabular}

$V$, current vector; $T$, temperature.

measurements were not made close enough to the bottom along the southern slope. Although westward bottom currents near the shelf edge have been inferred from density observations at other locations on the margin of Antarctica (KILLWORTH, 1983), such flow was unexpected along the northern edge of the South Shetland Islands.

In late 1980, ZEITSCHEL and ZENK (1981) obtained a set of moored current meter records at the base of the continental rise in water depth of $3625 \mathrm{~m}$ approximately $110 \mathrm{~km}$ north-northwest of Elephant Island. From this IfM mooring 270 (Fig. 5), WITTSTOCK and ZENK (1983) showed current and temperature records from 433, 1489 and $3590 \mathrm{~m}$ for 49 days beginning in December 1980. The deepest meter recorded westward flow along isobaths, while the overlying meters yielded more variable currents.

In an attempt to trace this westward slope current, Zenk placed a mooring (IfM 289) during 1983 in the passage between the Powell Basin and the Scotia Sea $\left(60^{\circ} 32.0^{\prime} \mathrm{S}\right.$, $48^{\circ} 18.8^{\prime} \mathrm{W}$ ) (Table 1). As seen in Figs 1 and 5, this location is to the western side of the passage and seems to be near sill depth in $1989 \mathrm{~m}$ of water. Both current meters showed persistent flow into the Scotia Sea (Table 2).

During the recovery of mooring 289 from the F.S. Polarstern, a zonal hydrographic section was made over the mooring location west of the South Orkney Islands (Fig. 5). The observations were reported and the temperature and salinity sections shown by ROHARDT (1984). The bottom profile shown was derived from the depths at the individual CTD stations.

In February 1984, Nowlin obtained four closely spaced hydrographic stations and expendable bathythermographs over the shelf break north of Elephant Island (Fig. 5) for the purpose of characterizing the waters of this slope current. The traditional station data, collected as part of the Ajax expedition aboard R.V. Knorr, are reported in the expedition data report (SIO/TAMU, 1985). The Ajax fluorocarbon-11 measurements we cite are from R. Weiss and J. BULLISTER (personal communication). They were measured by shipboard gas chromatography (WeIss et al., 1985) and are reported on the SIO 1986 calibration scale. The bottom distributions of water properties were constructed using the assembled historical data. To the Southern Ocean atlas data of GoRDON and MolinelLI (1982) we have added recent available cruise data, including ISOS measurements and Ajax expedition data. 
Table 2. Record length statistics

\begin{tabular}{|c|c|c|c|c|c|c|c|c|c|c|c|c|c|c|c|c|}
\hline \multirow[b]{2}{*}{ Mooring } & \multirow[b]{2}{*}{$Z(\mathbf{m})$} & \multirow{2}{*}{$\begin{array}{l}\text { Record } \\
\text { length }(d)\end{array}$} & \multicolumn{2}{|c|}{ Direction } & \multicolumn{4}{|c|}{$u\left(\mathrm{~cm} \mathrm{~s}^{-1}\right)$} & \multicolumn{4}{|c|}{$v\left(\mathrm{~cm} \mathrm{~s}^{-1}\right)$} & \multicolumn{4}{|c|}{$\begin{array}{l}\text { Potential temperature } \\
\qquad\left({ }^{\circ} \mathrm{C}\right)\end{array}$} \\
\hline & & & $V$ & Bath. & Mean & Min. & Max. & S.D. & Mean & Min. & Max. & S.D. & Mean & Min. & Max. & S.D. \\
\hline \multirow[t]{2}{*}{$\mathrm{ST}$} & 1400 & 388 & & & 0.9 & -15.6 & 16.7 & 5.7 & 0.8 & -11.7 & 9.5 & 3.4 & 0.86 & 0.43 & 1.06 & 0.17 \\
\hline & 2700 & 388 & $259^{\circ}$ & $252^{\circ}$ & -8.6 & -20.9 & 1.1 & 4.6 & 0 & -3.7 & 4.3 & 1.2 & 0.28 & 0.20 & 0.33 & 0.03 \\
\hline \multirow[t]{2}{*}{ SS 1000} & 200 & 383 & & & - & & & & - & & & & -0.19 & -1.79 & 0.95 & 0.51 \\
\hline & 510 & 272 & $240^{\circ}$ & $238^{\circ}$ & -3.0 & -21.8 & 19.3 & 7.0 & 0 & -7.3 & 5.1 & 1.6 & 0.88 & -0.60 & 1.68 & 0.54 \\
\hline SS 500 & 500 & 287 & $240^{\circ}$ & $238^{\circ}$ & -5.1 & -24.8 & 11.1 & 5.1 & 0 & -3.8 & 2.7 & 0.9 & 0.20 & -1.16 & 1.32 & 0.59 \\
\hline SP 501 & 500 & 395 & - & - & & & & & & & & & 0.38 & -0.87 & 1.37 & 0.51 \\
\hline \multirow[t]{2}{*}{270} & 1489 & 49 & & & -0.6 & -10.8 & 11.3 & 4.4 & -1.9 & -7.3 & 2.6 & 1.7 & 1.11 & 0.93 & 1.23 & 0.09 \\
\hline & 3590 & 49 & $227^{\circ}$ & $228^{\circ}$ & -21.1 & -27.0 & -6.4 & 5.1 & 0 & -6.8 & 2.9 & 1.6 & -0.26 & -0.35 & -0.16 & 0.05 \\
\hline \multirow[t]{2}{*}{289} & 1904 & 260 & & & -7.4 & -23.7 & 8.1 & 6.7 & 0.7 & -8.8 & 9.6 & 3.0 & -0.77 & -0.86 & -0.64 & 0.04 \\
\hline & 1964 & 262 & $305^{\circ}$ & - & -7.9 & -25.6 & 9.6 & 7.3 & 0 & -10.2 & 5.7 & 2.9 & -0.74 & -0.85 & -0.59 & 0.05 \\
\hline
\end{tabular}

$-u$ is oriented in direction of record-length mean of deepest current record.

$v$ is normal counterclockwise to $u$ to form right-hand coordinate system of $u, v$. 


\section{CURRENT PATHS AND WATER CHARACTERISTICS}

The bottom instruments at moorings 289,270, ST, SS100 and SS500 all indicate persistent flow along isobaths (Table 2): into the Scotia Sea at mooring 289, westward through the gap in the Shackleton Fracture Zone at mooring 270 and westward along the slope north of Livingston Island. In order to describe better the spreading of the deepest

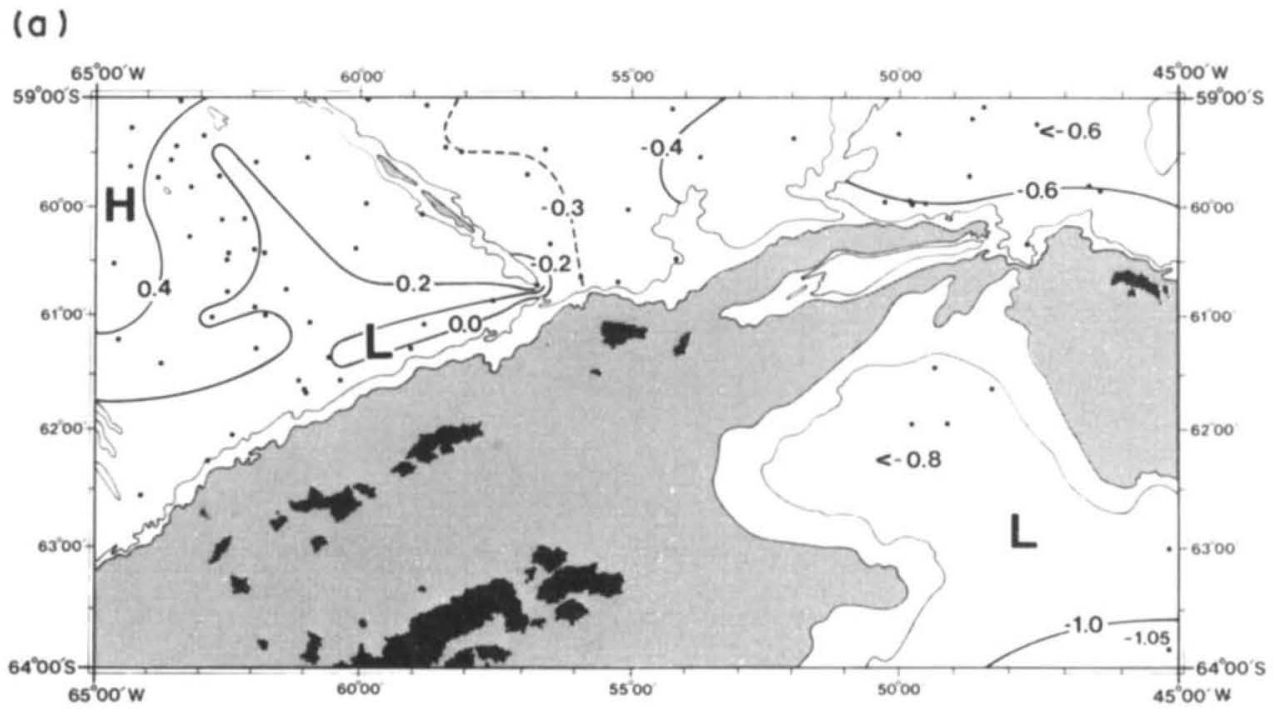

Fig. 6a.

(b)

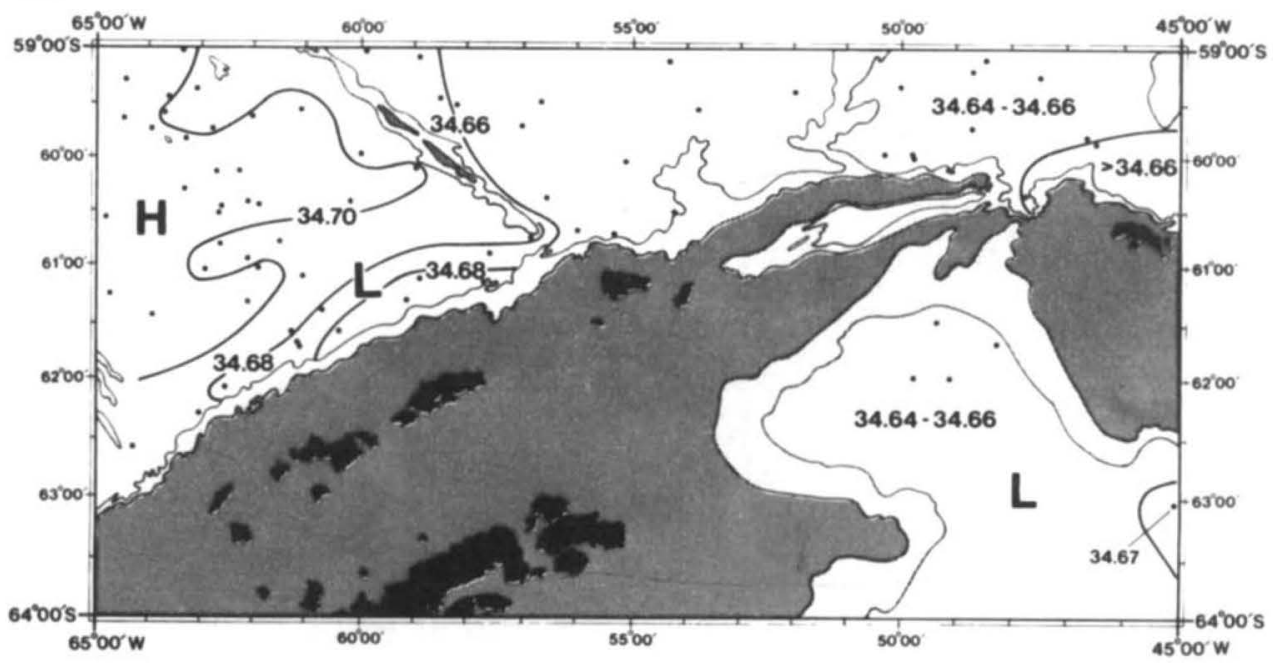

Fig. 6b. 
waters along the northern flank of the South Shetland Island Arc, we have constructed new distributions of bottom properties for the region $59-64^{\circ} \mathrm{S}$ and $45-65^{\circ} \mathrm{W}$.

Values of potential temperature, salinity, dissolved oxygen and silicate within $300 \mathrm{~m}$ of the bottom at stations with bottom depths of at least $3000 \mathrm{~m}$ were plotted and contoured (Fig. 6). Earlier, REID and NowLIN (1971) presented near-bottom distributions of

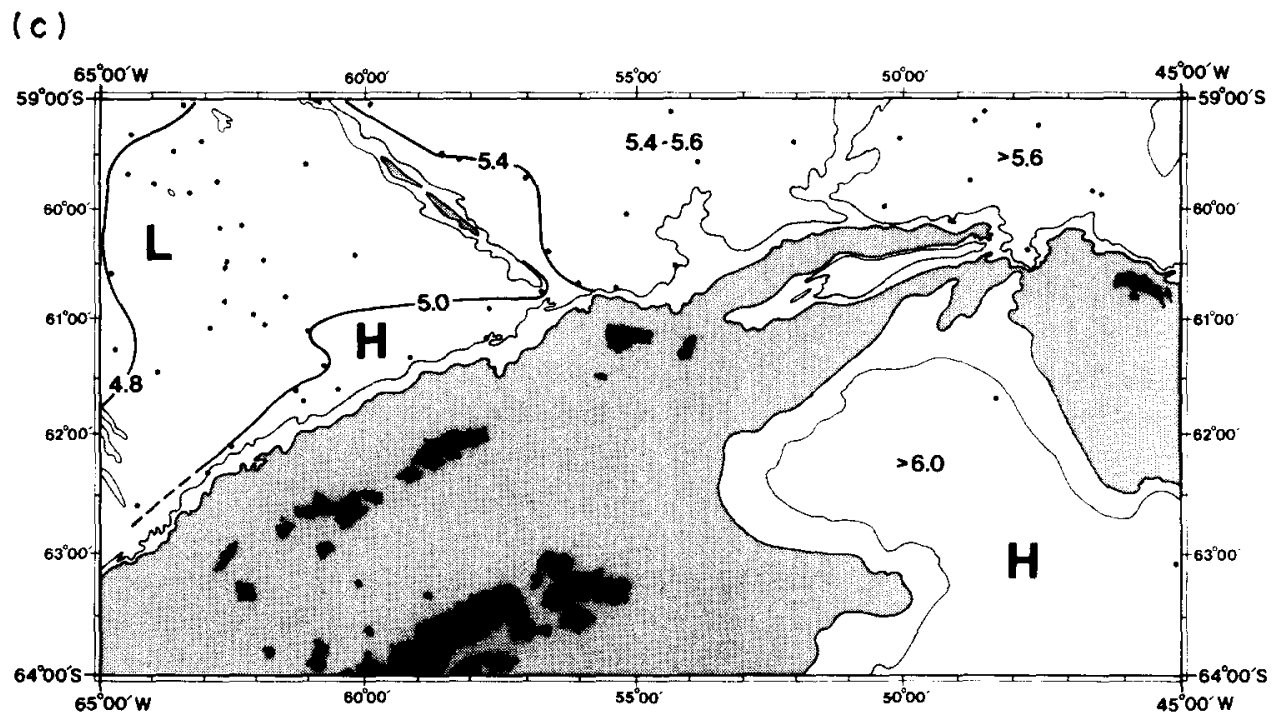

Fig. 6c.

(d)

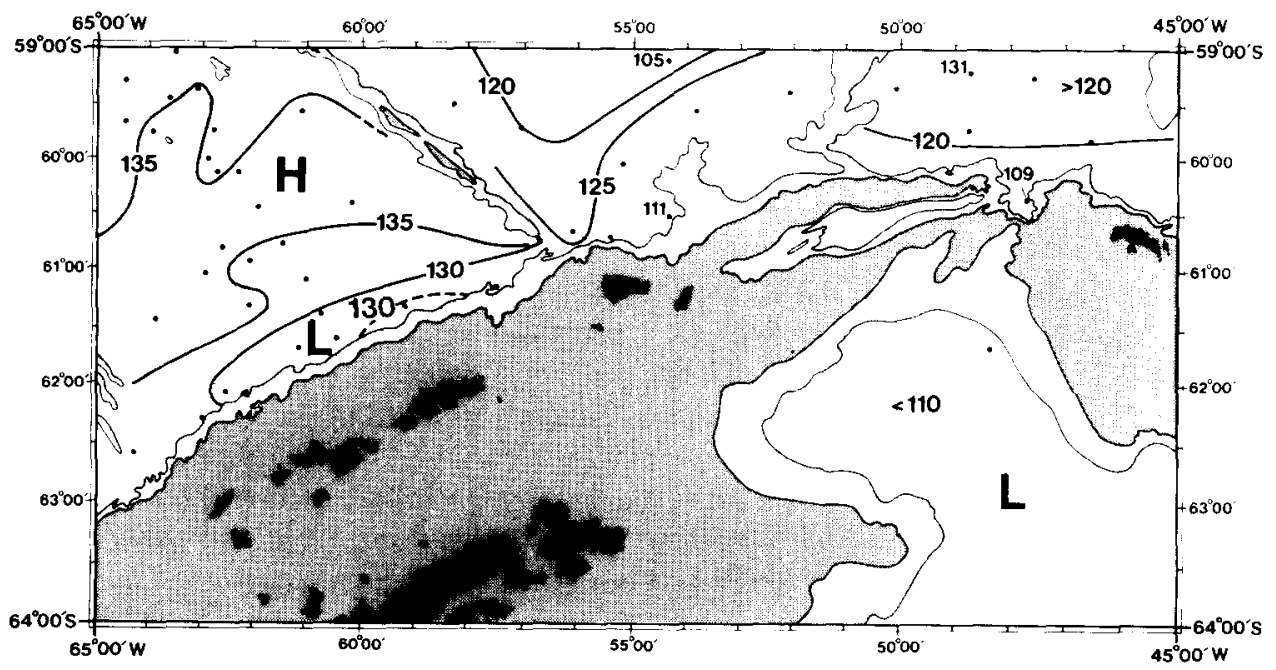

Fig. 6. (a) Potential temperature $\left({ }^{\circ} \mathrm{C}\right)$ within $300 \mathrm{~m}$ of the bottom for depths greater than $3000 \mathrm{~m}$ (no shading). Depths less than $2000 \mathrm{~m}$ are indicated by dark shading. (b) Salinity near the bottom, as in (a). (c) Dissolved oxygen $\left(\mathrm{ml} \mathrm{l}^{-1}\right)$ near the bottom, as in (a). (d) Silicate $\left(\mu \mathrm{mol} \mathrm{l}^{-1}\right)$ near the bottom, as in (a). 
potential temperature, salinity and sigma-4 for depths greater than $3000 \mathrm{~m}$ in the Drake Passage and adjacent regions $\left(50-70^{\circ} \mathrm{S}\right.$ and $\left.50-80^{\circ} \mathrm{W}\right)$, but many additional stations allow us to improve the resolution and also add silicate and oxygen distributions. (We have used only a representative subset of the ISOS materials available along the line between Cape Horn and Livingston Island, because too many are available to include them all.)

The bottom waters of the Weddell Sea are more oxygenated, somewhat fresher and considerably colder than those of the southwestern Scotia Sea. We have confirmed our bottom property distributions in the Weddell Sea by referring to the larger scale distributions given by MANTYLA and REID (1983) for that region. Bottom property values do not vary monotonically as one crosses the sill near $60.5^{\circ} \mathrm{S}, 48^{\circ} \mathrm{W}$ between the Powell Basin and the Scotia Sea. This is not unexpected, because the densest waters cannot cross that ridge, the sill depth of which is probably somewhat less than $2000 \mathrm{~m}$. The bottom waters in the Scotia Sea east of the meridional ridge at $51^{\circ} \mathrm{W}$ are denser than those at sill depth over this ridge; they have found their way from the Weddell Sea through the deeper gap near $40^{\circ} \mathrm{W}$, east of the South Orkney Islands.

The ridge of the Shackleton Fracture Zone, which extends northwest from Elephant Island, has a profound effect on the deep flow, and thus on distributions of characteristics (REID and Nowlin, 1971). With the newer data, we see that the ridge is not an effective barrier between the warmer, saltier Pacific waters and those of Weddell Sea origin in the southwest Scotia Sea.

The available bathymetric and hydrographic data indicate the existence of a gap between the base of the continental rise and the southeast end of the ridge which allows zonal communication of Weddell Sea Deep Water down to depths of perhaps $3500 \mathrm{~m}$. Weddell Sea Deep Waters in Drake Passage derived via the Scotia Sea were described in some detail by SIEVERS and Nowlin (1984), who showed them to be the densest waters in vertical section across the passage, where they fill the depression extending to greater than $5000 \mathrm{~m}$ north of Livingston Island (Fig. 1). Some waters with Weddell Sea characteristics may reach the Drake Passage by circumnavigating the ridge, the $3000-\mathrm{m}$ contour of which extends to at least $59.5^{\circ} \mathrm{S}, 59.5^{\circ} \mathrm{W}$ (KROENKE and WOLLARD, 1968) and may be farther (Fig. 1). However, we see in Fig. 6 that the most extreme properties of the relatively cold, oxygenated, fresh, low silicate bottom waters present from the Weddell Sea find their way westward through the forementioned gap and spread to the west-southwest along the base of the continental slope. The contoured fields show tongues separated from the continental slope corresponding to extreme bottom values found in the deepest portions of the trough. For example, R.V. Thompson 1976 Sta. 47 at $61.4^{\circ} \mathrm{S}, 60.8^{\circ} \mathrm{W}$ shows values at $4925 \mathrm{~m}$ of potential temperature, $-0.012^{\circ} \mathrm{C}$; dissolved oxygen, $4.98 \mathrm{ml} \mathrm{I}^{-1}$; salinity, 34.678 and silicate, $129.4 \mu \mathrm{mol} \mathrm{l}^{-1}$; data from this station in the deep trough ( $4943 \mathrm{~m}$ ) north of Livingston Island were used in the vertical sections by SiEvers and Nowlin (1984). There is some evidence for a secondary tongue of spreading toward the northwest from King George Island, perhaps influenced by the bathymetry. In any case the influence of the Weddell Sea Waters extends westward along the continental margin past the limit $\left(65^{\circ} \mathrm{W}\right)$ of our study area.

Sections of potential temperature, salinity, density, dissolved oxygen, silicate and fluorocarbon-11 over the shelf break and slope north of Elephant Island are shown in Fig. 7. The general features include the temperature minimum (Winter Water) of the Antarctic Surface Waters seen as a lens near $150 \mathrm{~m}$. At mid-depths we find remainders of the Lower Circumpolar Deep Water (LCDW), characterized by salinity maxima greater 
(a)

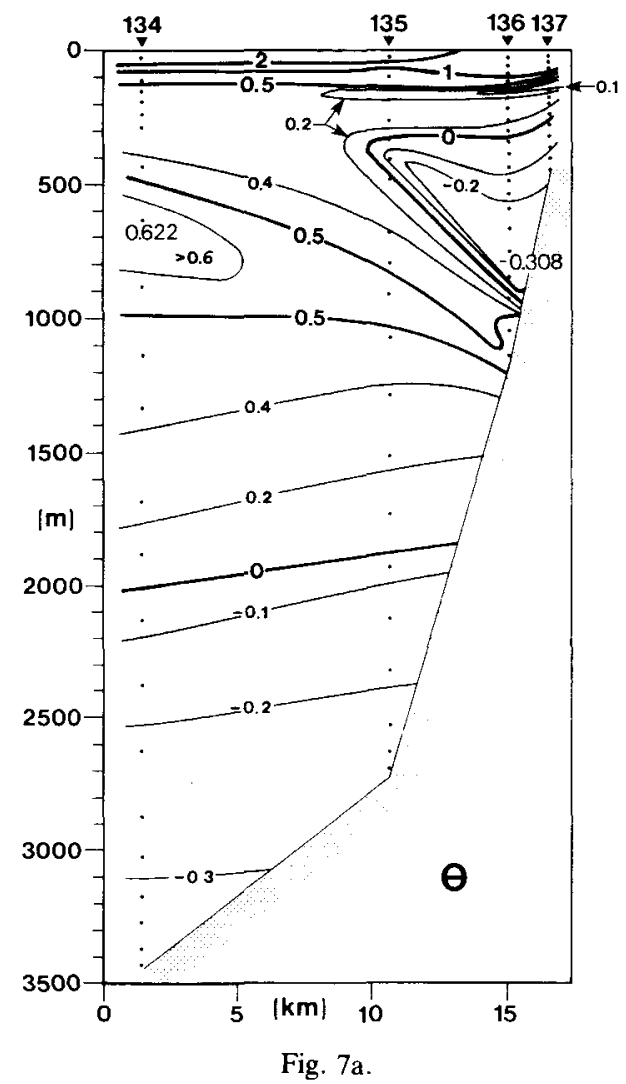

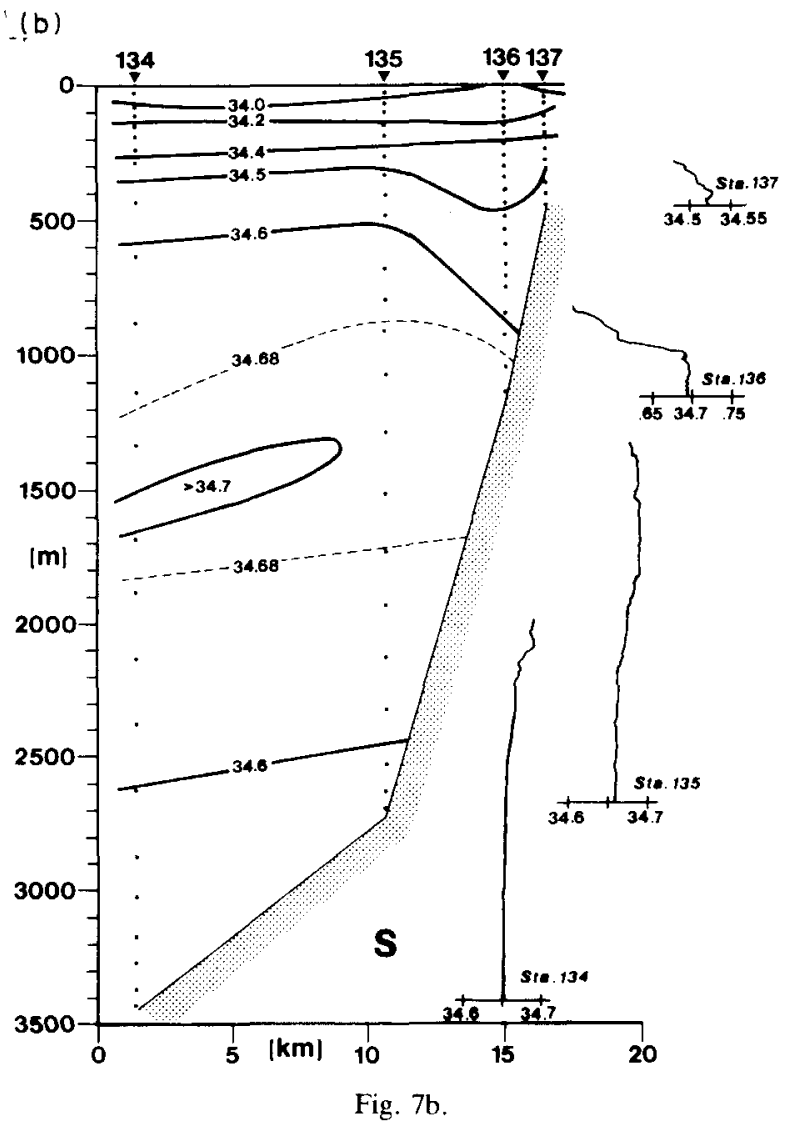


(c)

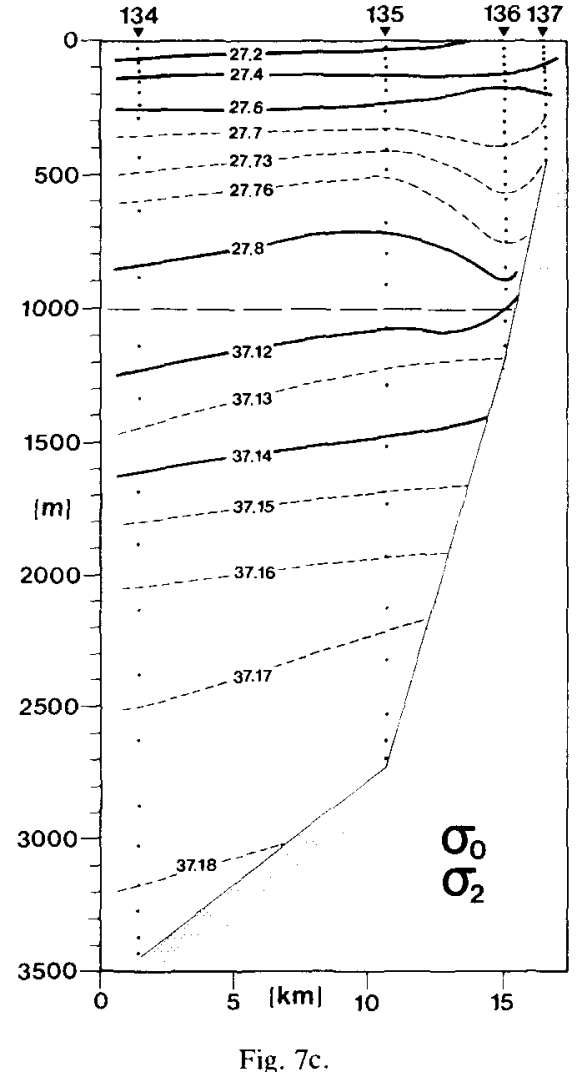

(d)

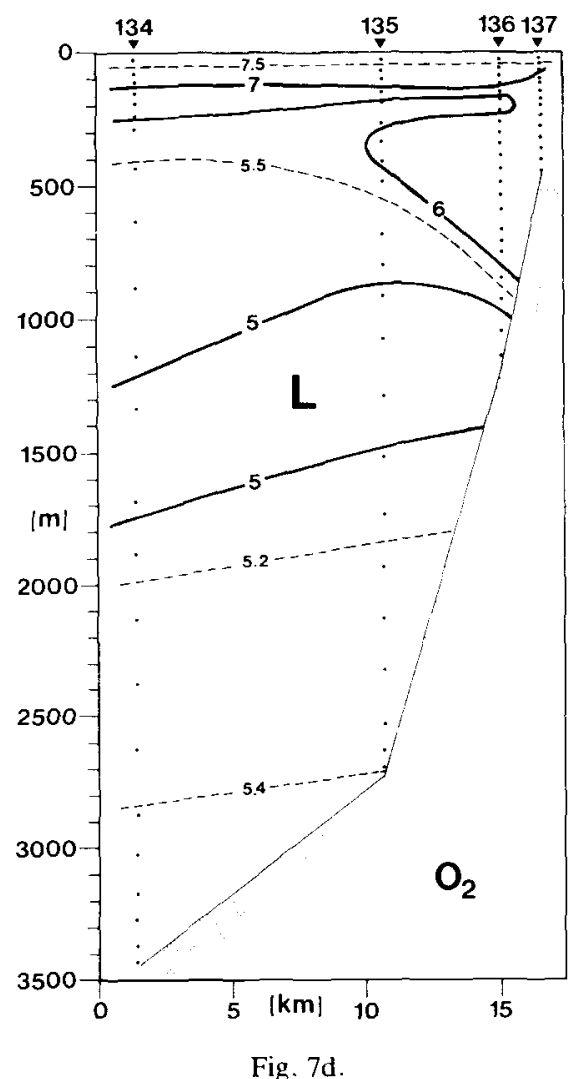


(e)

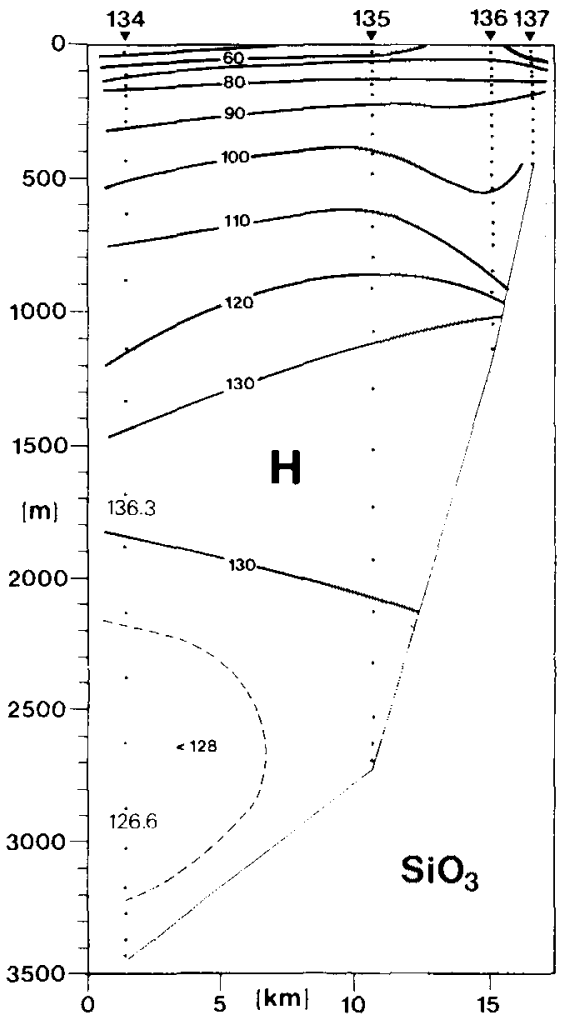

(f)

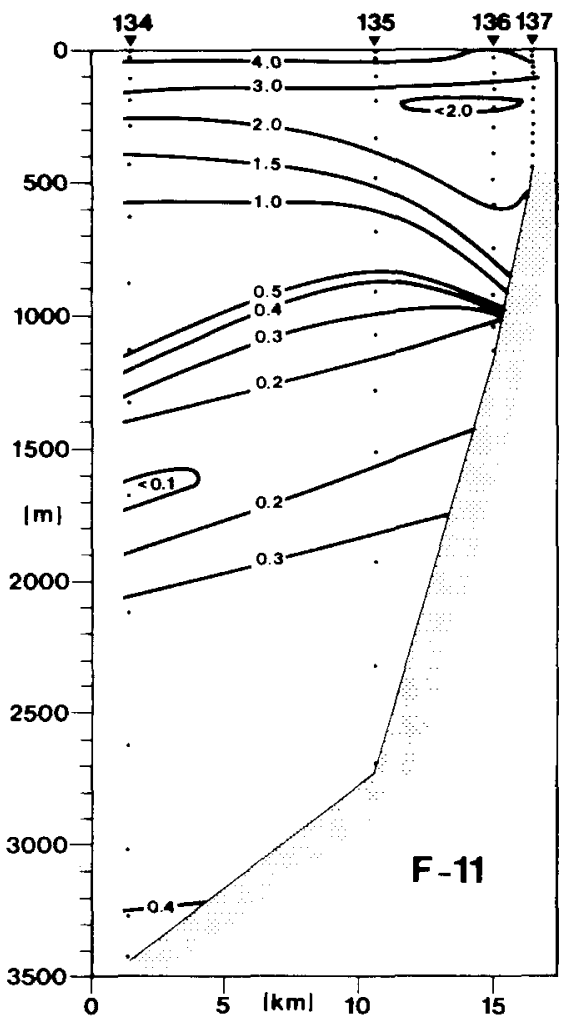

Fig. 7. (a) Potential temperature $\left({ }^{\circ} \mathrm{C}\right)$ over the shelf break and slope north of Elephant Island from stations made aboard R.V. Knorr in February 1984. Station positions shown in Fig. 5. (b) Salinity over the slope north of Elephant Island, as in (a). Near-bottom vertical profiles of salinity from CTD are shown. (c) Potential density anomaly $\left(\mathrm{kg} \mathrm{m}^{-3}\right.$ ) over the slope north of Elephant Island, as in (a). $\sigma_{0}$ for upper $1000 \mathrm{~m}, \sigma_{2}$ for greater depths. (d) Dissolved oxygen $\left(\mathrm{ml} \mathrm{l}^{-1}\right)$ over the slope north of Elephant Island, as in (a). (e) Silicate ( $\mu \mathrm{mol} \mathrm{l}^{-1}$ ) over the shelf north of Elephant Island, as in (a). (f) Fluorocarbon-11 (pmol $\mathrm{kg}^{-1}$ ) over the slope north of Elephant Island, as in (a) 
than 34.7 , located near $\sigma_{2}$ values of 37.14 . The minimum in fluorocarbon-11 $\left(<0.1 \mathrm{pmol} \mathrm{kg}^{-1}\right)$ is consistent with the concept of older LCDW. Just below the LCDW we see a trace of fluorocarbon-11 near $1700 \mathrm{~m}$ at Sta. 134 of the Southeast Pacific Deep Water as described in the Drake Passage (SiEvers and Nowlin, 1984); values within that water characteristically reach or exceed $135 \mu \mathrm{mol} \mathrm{l}^{-1}$. Below that, in the very deep waters, we see lower silicate, temperature and salinity values characteristic of origins in the Weddell Sea. The deepest values of characteristics at Sta. 134 have been used in constructing Fig. 6, and so are consistent with the pictured bottom distributions.

As in other sections over the shelf break around Antarctica, the water at the bottom on the shelf and along the slope is denser (colder) than that just offshore (note the upward tilt of isopycnals to the south in Fig. 7c). There is the indication of relatively cold, fresh, oxygenated, low silicate water extending from the shelf approximately $800 \mathrm{~m}$ down the upper slope. The fluorocarbon-11 distribution confirms the existence of waters along the upper slope which contain a larger component of recently ventilated water than their offshore or subjacent neighbors. The extension offshore is at least $8 \mathrm{~km}$ but not more than $15 \mathrm{~km}$, the same order as the local Rossby deformation radius. This is consistent with the idea of a slope current driven by thermohaline convection from the shelves (KILlWORTH, 1983).

The high fluorocarbon-11 and relatively low silicate values in the bottom boundary layer at Sta. 134 are indicative of the younger Weddell Sea Water beneath the circumpolar waters. This westward flow along the slope base may be a part of the deep thermohaline circulation and locally unassociated with the upper westward slope current. However, conditions are correct in some regions for the further downward convection of the slope current waters to contribute to such deep and bottom water currents (KILLWORTH, 1983).

At all four Ajax CTD stations (134-137) a quasi-homogeneous bottom boundary layer was observed. Near-bottom salinity profiles are shown on the salinity section across the slope off Elephant Island (Fig. 7b). We can distinguish between a thicker, more uniform type of boundary layer at depths greater than $2000 \mathrm{~m}$ and a thinner, though welldeveloped, layer beneath the complex stratification characteristics of the upper slope and shelf. A similar classification was used by ARMI and MILLARD (1976) for boundary layers observed, respectively, in the central Hatteras Plain and near the margins of the abyssal plain with rough or more sloping topography. Our direct current observations at different locations confirm the thesis that the well-mixed region of the bottom boundary layer is a dynamical feature of the deep westward current along the slope.

A section of closely spaced XBTs (Fig. 8) was made along a line slightly to the west of the hydrographic stations of Fig. 7. The onshore extent of the cold water is better resolved as are small-scale structures, especially small lenses with temperatures less than $-0.2^{\circ} \mathrm{C}$. The general structure is similar to that in Fig. 7a, except that the Winter Water temperature minimum is not found over the slope and the Upper Circumpolar Deep Water has a much warmer signal.

The east-west temperature section (Fig. 9) along the ridge between the Weddell and Scotia seas was adapted from the Polarstern cruise report (ROHARDT, 1984). (Mooring 289 was situated near CTD Sta. 238.) The upper and intermediate water masses are similar to the distributions off Elephant Island. Below the Antarctic Surface Water (marked by Winter Water with potential temperature minima $<-1.0^{\circ} \mathrm{C}$ ) we find the Lower Circumpolar Deep Water with its characteristic salinity maximum at about $750 \mathrm{~m}$ 


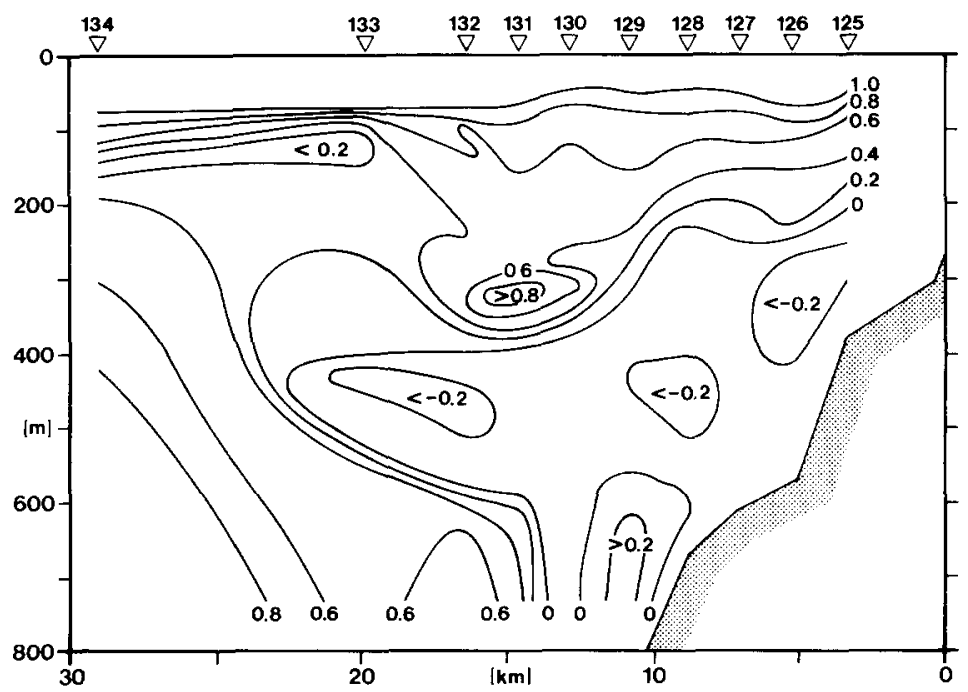

Fig. 8. Temperature $\left({ }^{\circ} \mathrm{C}\right)$ of the upper waters over the outer shelf and slope off Elephant Island as obtained from XBTs. These data were collected aboard R.V. Knorr while proceeding to the northeast somewhat west of the line of Stas 134-137 some hours after their occupation.

(not shown here). We note that this core lies shallower than off Elephant Island (Fig. 7b), consistent with the poleward ascent of isopycnals. Of particular interest are the tilted near-bottom isotherms (potential temperature $<-0.4^{\circ} \mathrm{C}$ ) which are indicative of the outflow of Weddell Sea Deep Water (WSDW) into the Scotia Sea.

A meridional section across the ridge separating the Powell and Scotia basins is presented in Fig. 10. Although not synoptic with mooring 289, these data, collected

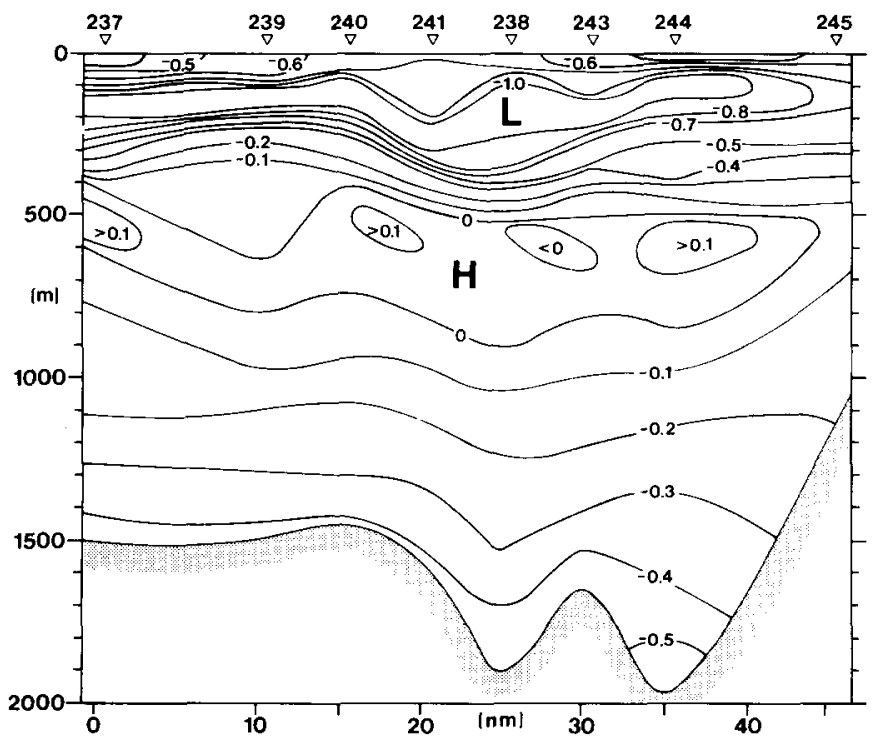

Fig. 9. Potential temperature $\left({ }^{\circ} \mathrm{C}\right)$ in zonal vertical section west of the South Orkney Islands (see Fig. 5 for locations) as observed in December 1983 from the R.V. Polarstern (after ROHARDT, 1984). Bottom topography between CTD stations has been interpolated. 
(a)

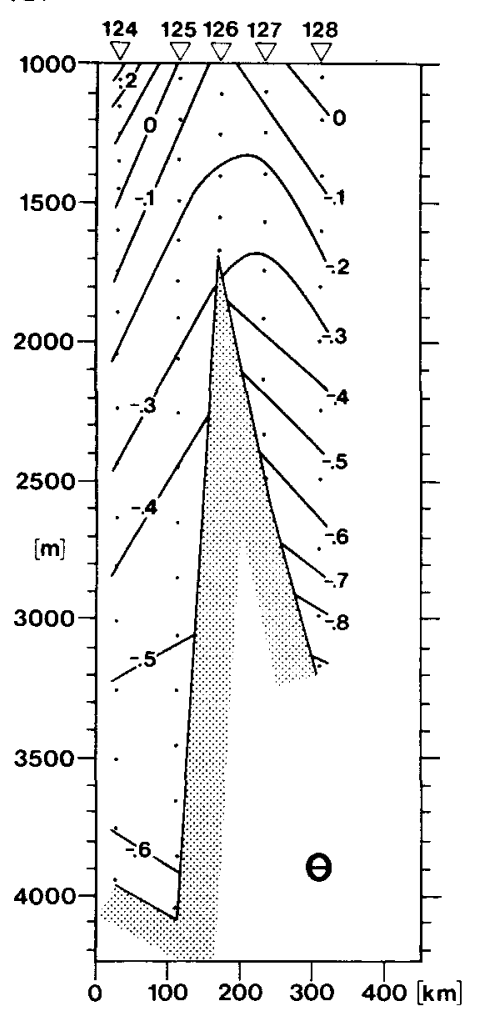

Fig. 10a. (b)

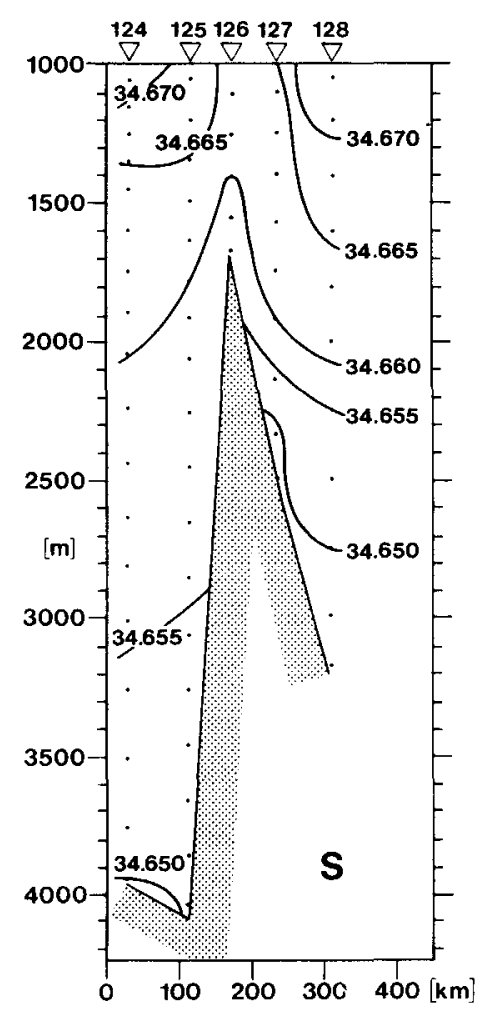

Fig. $10 \mathrm{~b}$. (c)

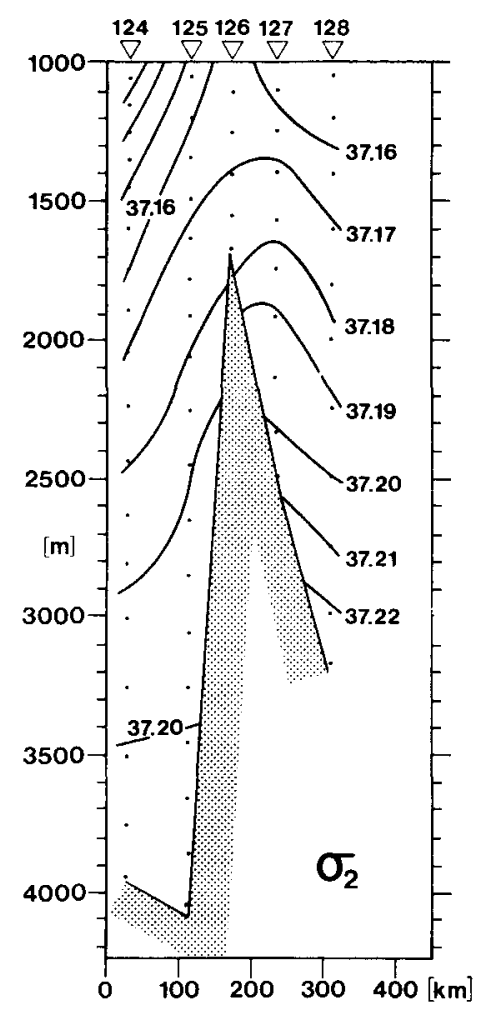

Fig. 10c. 
(d)

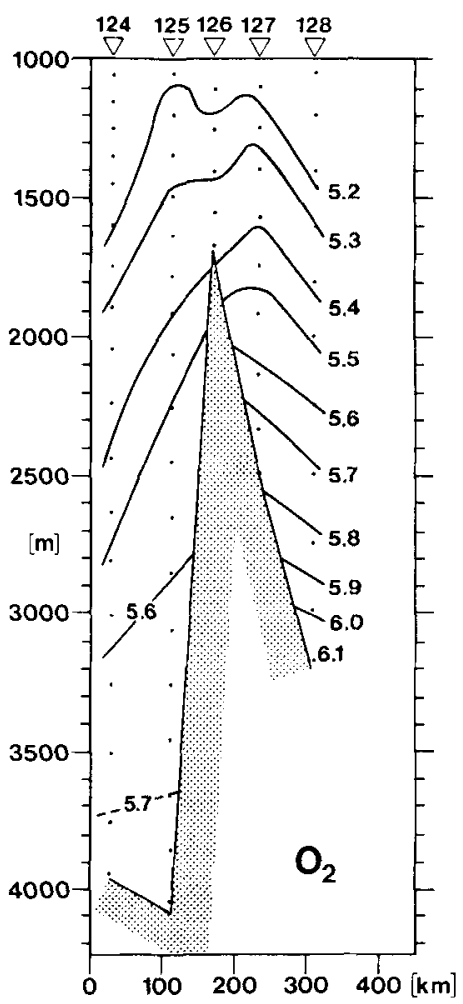

(e)

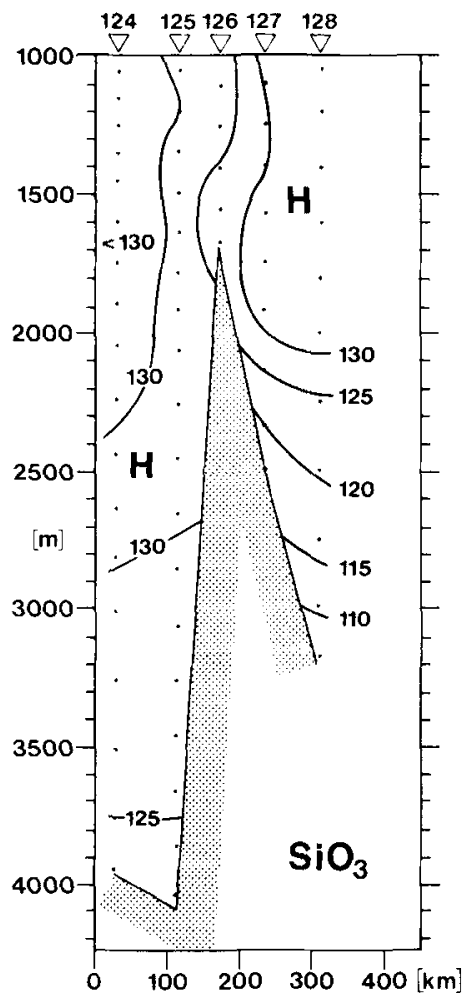

(T)

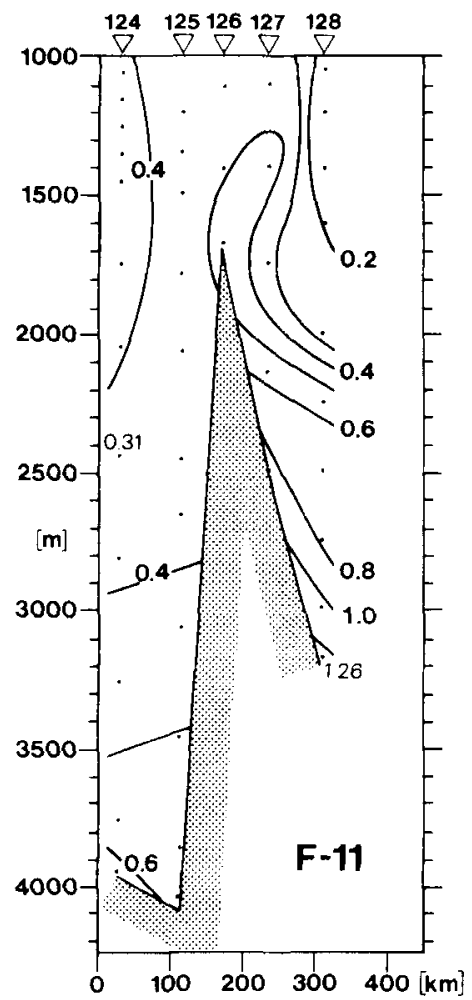

Fig. 10. (a) Potential temperature $\left({ }^{\circ} \mathrm{C}\right)$ for depths greater than $1000 \mathrm{~m}$ in meridional vertical section from Scotia Sea to Powell Basin along approximately $48^{\circ} \mathrm{W}$ (location shown in Fig. 5). Stations made during February 1984 aboard R.V. Knorr on the Ajax expedition. (b) Salinity in vertical section as in (a). (c) $\sigma_{2}$ (kg m ${ }^{-3}$ )

in vertical section as in (a). (d) Dissolved oxygen $\left(\mathrm{ml} \mathrm{l}^{-1}\right)$ in vertical section as in (a). (e) Silicate ( $\mu$ mol $\left.\mathrm{l}^{-1}\right)$ in vertical section as in (a). (f) Fluorocarbon-11

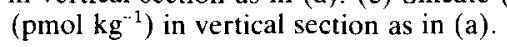


during the Ajax expedition in February 1984, complement the zonal section occupied the year before by Polarstern. Because our main interest is in the deep stratification, we have restricted the portrayal to depths greater than $1000 \mathrm{~m}$.

Two distinct regimes are seen separated by the Scotia Ridge. The upward tilting isopleths south of the ridge reflect the deep cyclonic Weddell Sea circulation. North of the ridge the deep flow could be westward with a mid-depth or upper velocity reference level (or eastward with a near-bottom reference). Of special interest is the observation that property values found at or near sill depth on the south flank of the ridge are found $500-1000 \mathrm{~m}$ deeper on the northern flank. Many of the characteristic distributions, particularly those of fluorocarbon-11 and silicate, indicate vertical plumes extending upward from the south flank above the local ridge crest. These might be interpreted as evidence of local or upstream overflow of Weddell Sea Deep Water.

Based on the traditional criterion (potential temperature $<-0.9^{\circ} \mathrm{C}$ ), the deepest waters at Sta. 128 in the Powell Basin are Weddell Sea Bottom Waters (WSBW). Moreover, values of salinity, dissolved oxygen and silicate correspond to characteristic values for WSBW as tabulated by WEIss et al. (1979). Values of fluorocarbon-11 within these WSDW at the time of Ajax measurements were $\geqslant 1.2 \mathrm{pmol} \mathrm{kg}^{-1}$.

In the section of Fig. 10, no WSBW appears on the Scotia Sea side of the ridge. But, based on the classical criteria (salinity $<34.66$, potential temperature $<-0.4^{\circ} \mathrm{C}$ ), the waters below about $2500 \mathrm{~m}$ on the northern side of the ridge are Antarctic Bottom Water (specifically, WSDW). The deepest waters north of the ridge have the same WSDW characteristics as those found near $2200-2500 \mathrm{~m}$ just south of the ridge. The high fluorocarbon-11 and low silicate, particularly, are consistent with a recent origin of these waters.

4. MOOREDARRAYMEASUREMENTS

\section{Current and temperature time series}

Shown in Fig. 11 are bi-daily current vectors of 40-h low-pass filtered records from ISOS moorings ST, SS1000 and SS500. Moorings SS500 and SS1000 were located quite close $(4.1 \mathrm{~km}$ apart) on the outer continental shelf and upper slope. The vector time series $100 \mathrm{~m}$ above the bottom at SS500 shows currents which are remarkably uniform in direction, though variable in magnitude. The visual impression is that directional variability increases with increasing distance above the bottom $(370 \mathrm{~m}$ for the deepest instrument on ST and $485 \mathrm{~m}$ for SS1000). However, all three near-bottom records show westward flow, generally oriented in the same direction. They all differ in character from the intermediate depth record $(1400 \mathrm{~m})$ on mooring ST.

From available bathymetric charts, local contours were oriented along $252^{\circ}$ at ST and $238^{\circ}$ at SS1000 and SS500. The record-length mean velocity components were used to determine mean directions, which were $259^{\circ}$ for ST at $2700 \mathrm{~m}$ and $240^{\circ}$ for SS500 and SS1000. These directions are remarkably close to the isobath directions and were selected for further study. In the remainder of this paper $-u$ is oriented in the direction of the record-length mean at the deepest current record on each mooring (e.g. positive toward $78^{\circ}$ for $\mathrm{ST}$ and $60^{\circ}$ for SS500 and SS1000) and $v$ denotes cross-isobath flow (positive toward $349^{\circ}$ and $330^{\circ}$ for the ST and S moorings, respectively).

The current vectors from IfM mooring 270 (Fig. 12) show a pattern quite similar to those from mooring ST, though the duration is shorter. The deepest record, from only 

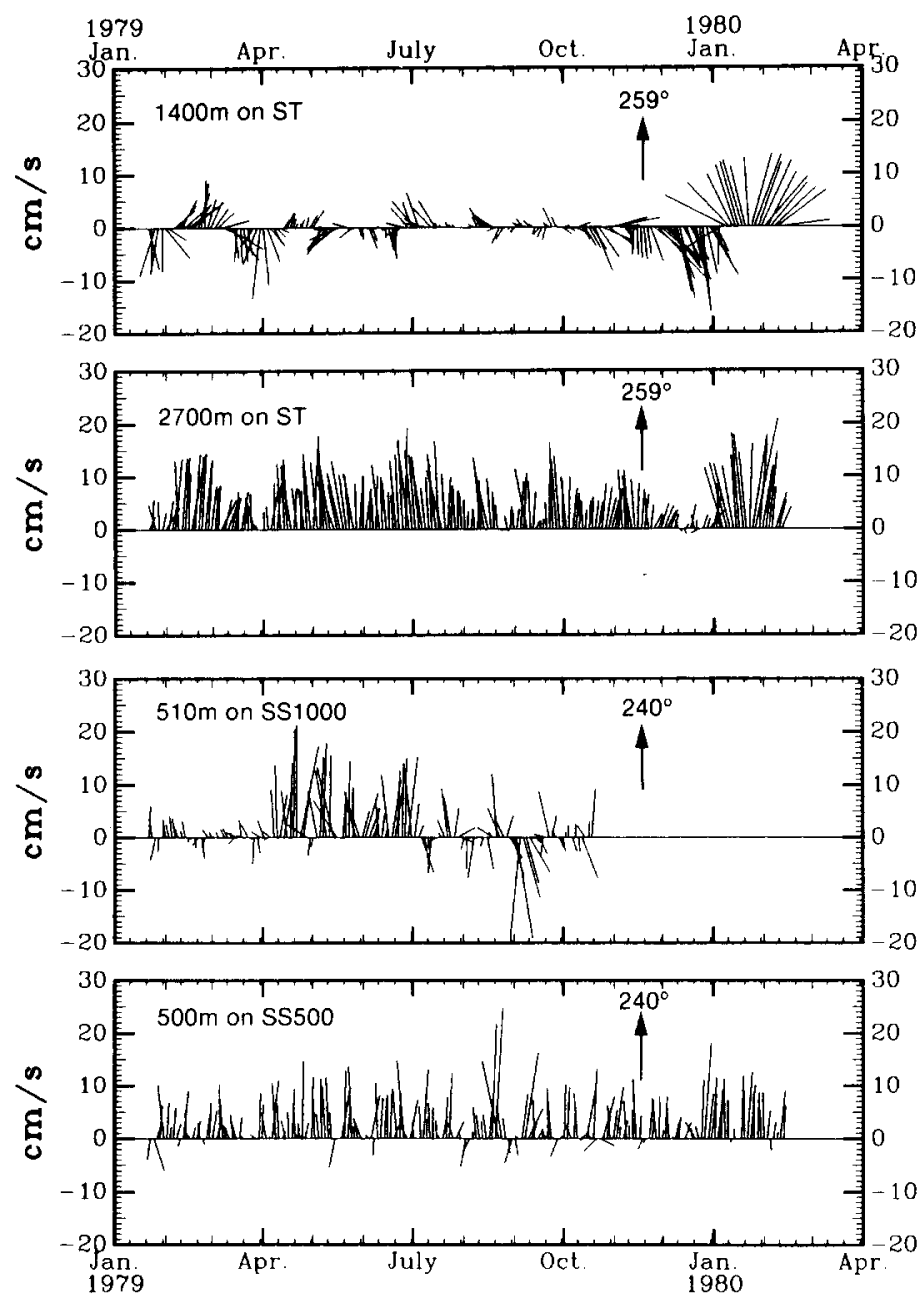

Fig. 11. Vector time series of current measured at 1400 and $2700 \mathrm{~m}$ on mooring ST (water depth $3070 \mathrm{~m}$ ), $510 \mathrm{~m}$ at SS1000 (water depth $995 \mathrm{~m}$ ) and $500 \mathrm{~m}$ at SS500 (water depth $600 \mathrm{~m}$ ) at locations shown in Fig. 5. Hourly values were 40-h low-pass filtered and one vector plotted from every second day. The record-length mean direction of the deepest meter on each mooring is indicated.

$35 \mathrm{~m}$ above the bottom, is directed persistently toward $227^{\circ}$; the isobath orientation is along $228^{\circ}$. Near $1500 \mathrm{~m}$ there is no visible evidence of the westward bottom current. The mean along-isobath velocity component at $3590 \mathrm{~m}$ on mooring 270 is considerably larger $\left(21 \mathrm{~cm} \mathrm{~s}^{-1}\right)$ than at any other instrument (Table 2$)$. This may be because the mooring was located (Fig. 1) just west of the gap between the continental slope and the ridge of the Shackleton Fracture Zone. This gap is rather narrow at $3000-\mathrm{m}$ depth, approximately $12 \mathrm{~km}$, yet is the principal gate through which waters at and below that depth flow to the west as discussed in Section 3 (see Fig. 6).

The currents from the two meters on IfM mooring 289 (Fig. 13) visually are not nearly as persistent in direction as the other near-bottom records, although both meters were 


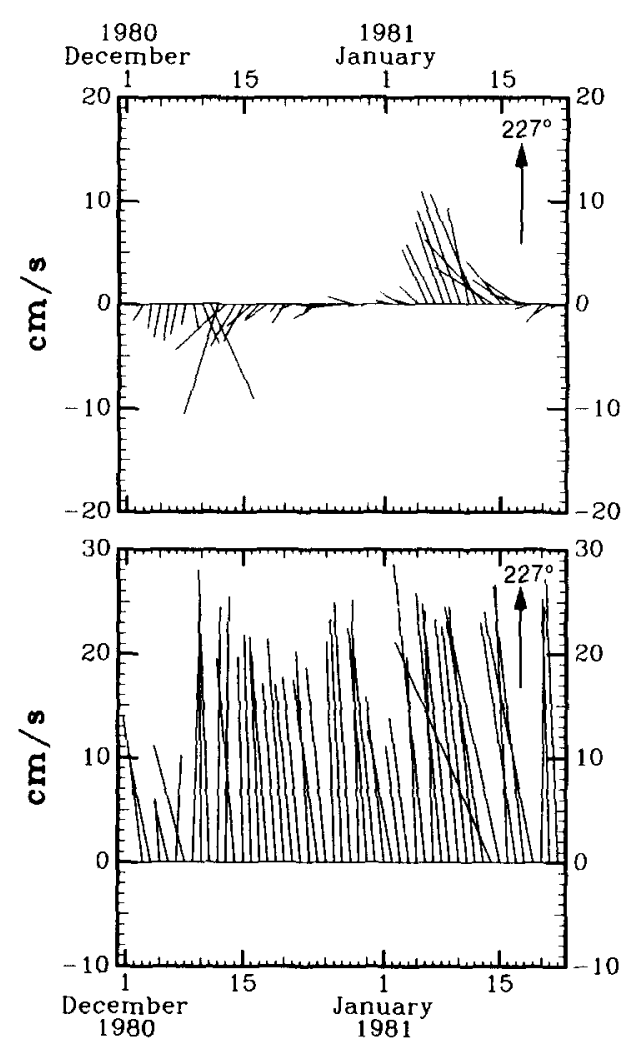

Fig. 12. Vector time series of current measured at 1489 (upper panel) and $3590 \mathrm{~m}$ on mooring 270 (water depth $3625 \mathrm{~m}$ ) at location shown in Fig. 5. Hourly values were 40 -h low-pass filtered and one vector plotted from each day. The record-length mean direction at $3590 \mathrm{~m}$ is indicated.

within $85 \mathrm{~m}$ of the bottom. This is confirmed by the relatively large $\left(3 \mathrm{~cm} \mathrm{~s}^{-1}\right)$ standard deviation of the current component $v$, normal to the record-length mean direction (Table 2). Both instruments appear to have been responding to the same flow variability. The bathymetric data are insufficient to enable us to say how close the mean direction of $305^{\circ}$ corresponds to the strike of isobaths at this mooring. It appears, however, that mooring 289 was located near the crest of a ridge separating the Powell Basin from the Scotia Sea. The flow is likely turning counterclockwise as it flows over this ridge, although the local bathymetry doubtless influences the flow direction. Based on bathymetry made during the CTD section over the mooring location (Fig. 9), this mooring was located near the bottom of a depression some $13 \mathrm{~km}$ in zonal extent at $1700 \mathrm{~m}$ depth.

For the potential temperature records from the moored instruments, the general pattern of variability at mooring ST (Fig. 14) appears similar at the two depths (as confirmed for longer periods by coherence estimates), though short-period variations are distinctly dissimilar. This probably reflects the well-documented vertical coherence of large-scale thermohaline features at Drake Passage (see e.g. Sciremammano et al., 1980). The mean values of 0.86 and $0.28^{\circ} \mathrm{C}$ at 1400 and $2700 \mathrm{~m}$ agree well with values shown by SIEVERS and Nowlin (1984) at this location in their vertical sections. 


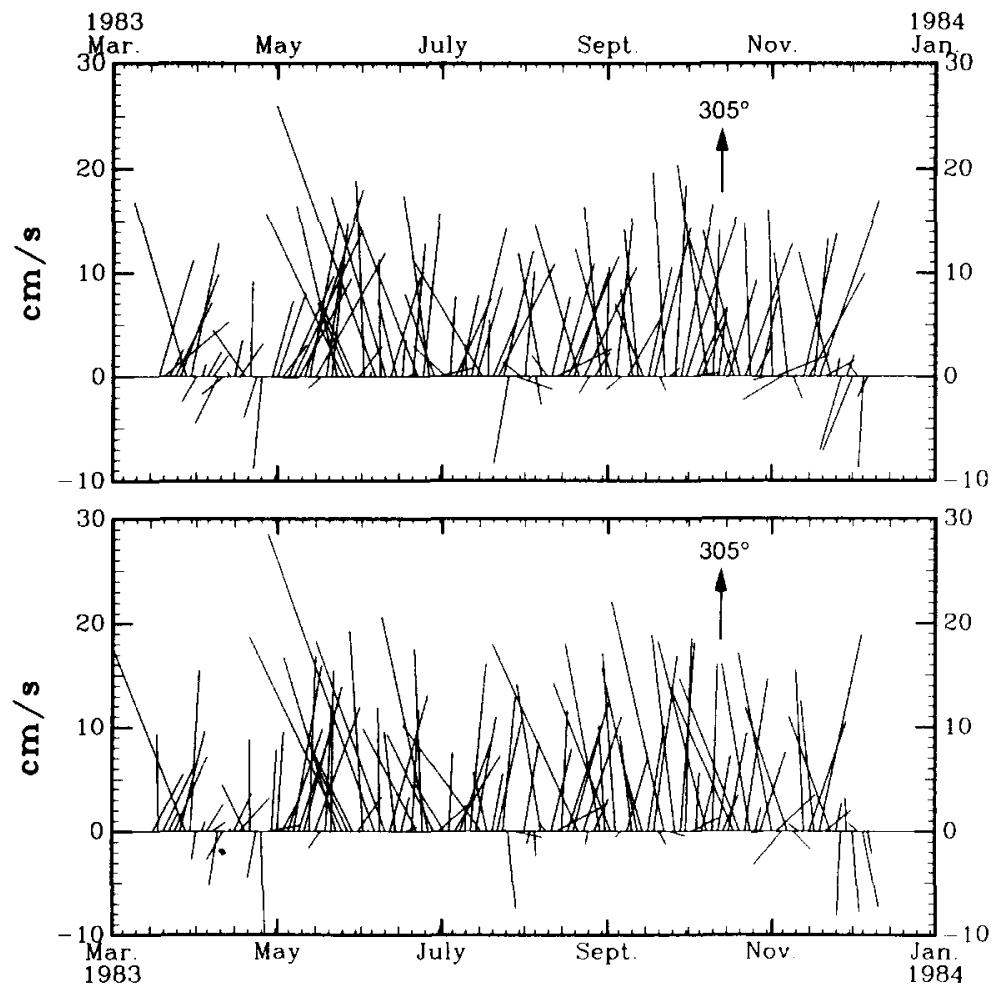

Fig. 13. Vector time series of current measured at 1904 (upper panel) and $1964 \mathrm{~m}$ on mooring 289 (water depth $1989 \mathrm{~m}$ ) at location shown in Fig. 5. Hourly values were 40-h low-pass filtered and one vector plotted from every second day. The record-length mean direction at $1964 \mathrm{~m}$ is indicated.
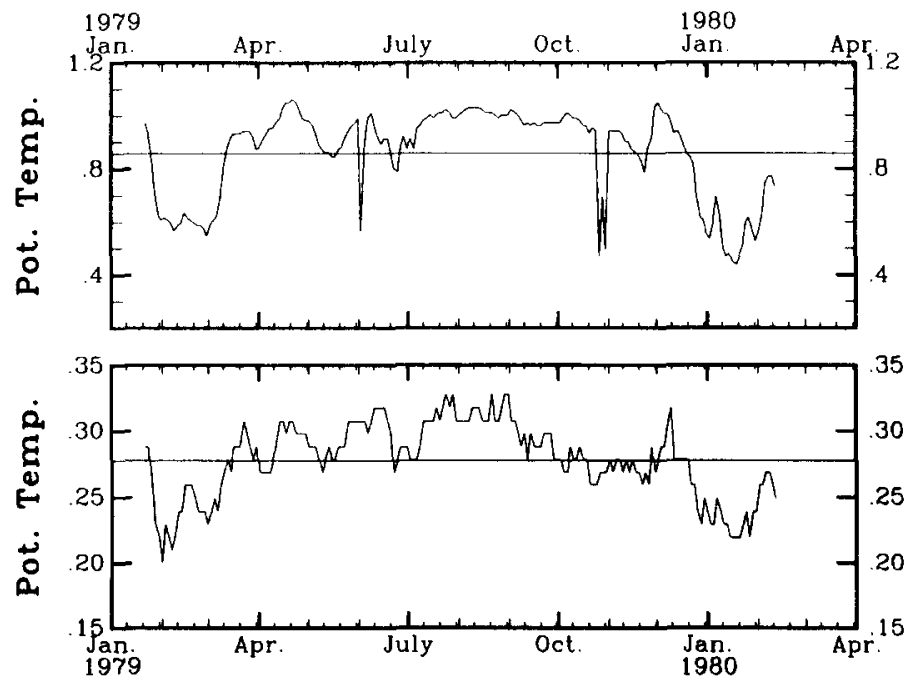

Fig. 14. Potential temperature $\left({ }^{\circ} \mathrm{C}\right.$ ) measured at 1400 (upper panel) and $2700 \mathrm{~m}$ on mooring ST at location shown in Fig. 5. A 40-h low-pass filter was applied and one value plotted every second day. Note very different temperature scales are used for these plots. 
The potential temperature records from 200 and $510 \mathrm{~m}$ at mooring SS1000, $500 \mathrm{~m}$ at SS500 and $500 \mathrm{~m}$ at SP501 (Fig. 15) show fair to good visual correspondence of variability; the correspondence with the $200-\mathrm{m}$ record is less clear. (These relations are developed further in the next subsection to yield information regarding the spatial extent and coherence of the westward slope current.) Mean values at $500 \mathrm{~m}$ on the outer shelf $\left(0.20\right.$ and $0.38^{\circ} \mathrm{C}$ from Table 2) are somewhat less than the $500-\mathrm{m}$ mean value offshore in 1000 -m water depth $\left(0.88^{\circ} \mathrm{C}\right)$. This is consonant with colder water lying over the shelf and shelf break as discussed in Section 3 of this paper and seen in many potential temperature sections across Drake Passage (e.g. Sievers and Nowlin, 1984, figures 3 and 4).

The temperature series from 1489 and $3590 \mathrm{~m}$ at mooring 270 (Fig. 16) show very dissimilar records, unlike the two records on mooring ST (Fig. 14). The lower meter at
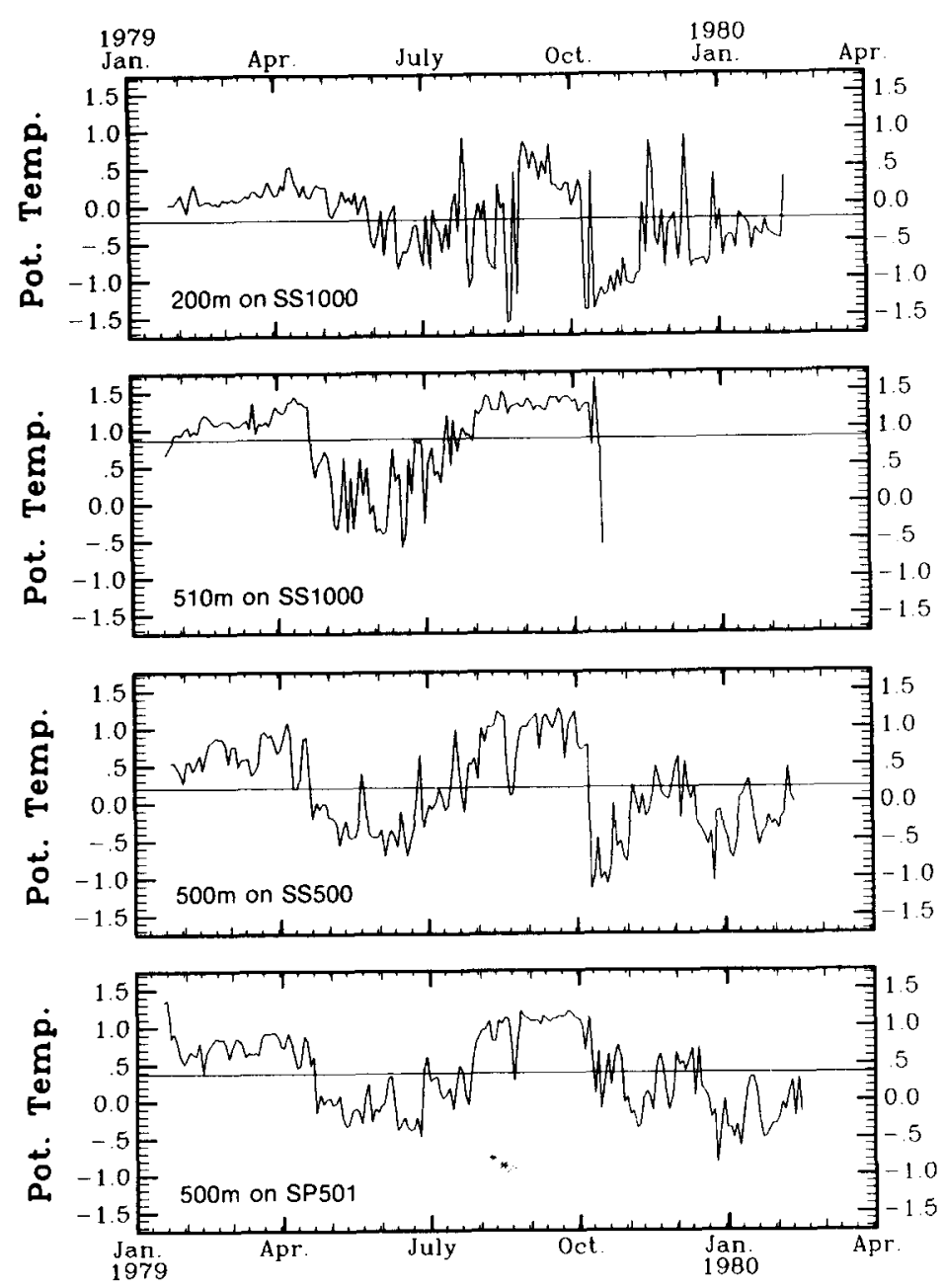

Fig. 15. Potential temperature $\left({ }^{\circ} \mathrm{C}\right)$ measured at 200 and $510 \mathrm{~m}$ on mooring SS1000, at $500 \mathrm{~m}$ on mooring SS500 and at $500 \mathrm{~m}$ on mooring SP501. A 40-h low-pass filter was applied and one value plotted every second day. 


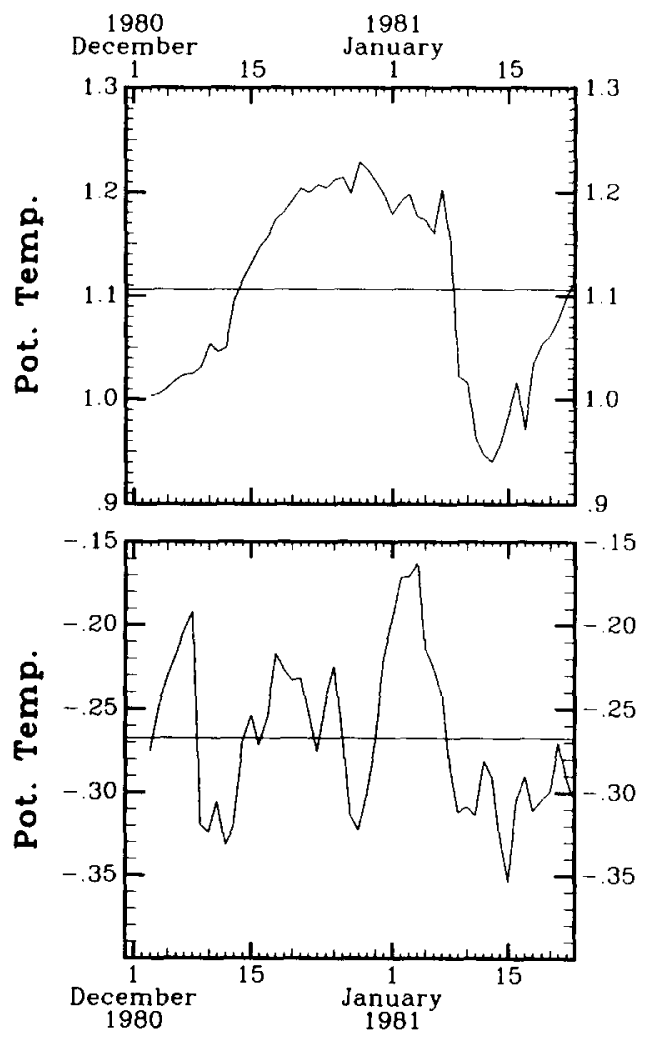

Fig. 16. Potential temperature $\left({ }^{\circ} \mathrm{C}\right.$ ) measured at 1489 (upper panel) and $3590 \mathrm{~m}$ on mooring 270. A 40-h low-pass filter was applied and one value plotted every second day.

mooring 270 was in the bottom boundary layer ( $35 \mathrm{~m}$ off the bottom), whereas the lower instrument at mooring ST was $370 \mathrm{~m}$ above the bottom and likely above or in the upper part of the boundary layer-judging thicknesses by their values off Elephant Island (see Section 3). The mean temperature at $3590 \mathrm{~m}$ is $-0.26^{\circ} \mathrm{C}$, somewhat higher than the bottom $(3430 \mathrm{~m})$ temperature of $-0.326^{\circ} \mathrm{C}$ found north of Elephant Island (Sta. 134 in Fig. 7a), in agreement with a westward bottom temperature increase along this slope (Fig. 6a).

The mean values of potential temperature from 1904 and $1964 \mathrm{~m}$ on mooring 289 (Fig. 17) are -0.77 and $-0.74^{\circ} \mathrm{C}$, respectively. CTD Sta. 238 (Fig. 9) was made in corrected water depth of $1936 \mathrm{~m}$ just after recovery at the mooring site. That station evidenced a well-mixed bottom boundary layer with a thickness of $120 \mathrm{~m}$ and potential temperature of $-0.47^{\circ} \mathrm{C}$ (confirmed by reversing thermometers in two bottles). This temperature is considerably warmer than recorded at similar depths on mooring 289 . Moreover, the potential temperature at Knorr Sta. 126, located approximately $15 \mathrm{~km}$ northwest in $1689 \mathrm{~m}$ of water, was $-0.276^{\circ} \mathrm{C}$ at $1666 \mathrm{~m}$ (Fig. 10a). Because the current meters on mooring 289 had no pressure sensors, the water depth at the mooring site may have been greater than reported. From the Polarstern and Knorr cruises it is clear that the local topography is complex, and unresolved by our bathymetric charts. 

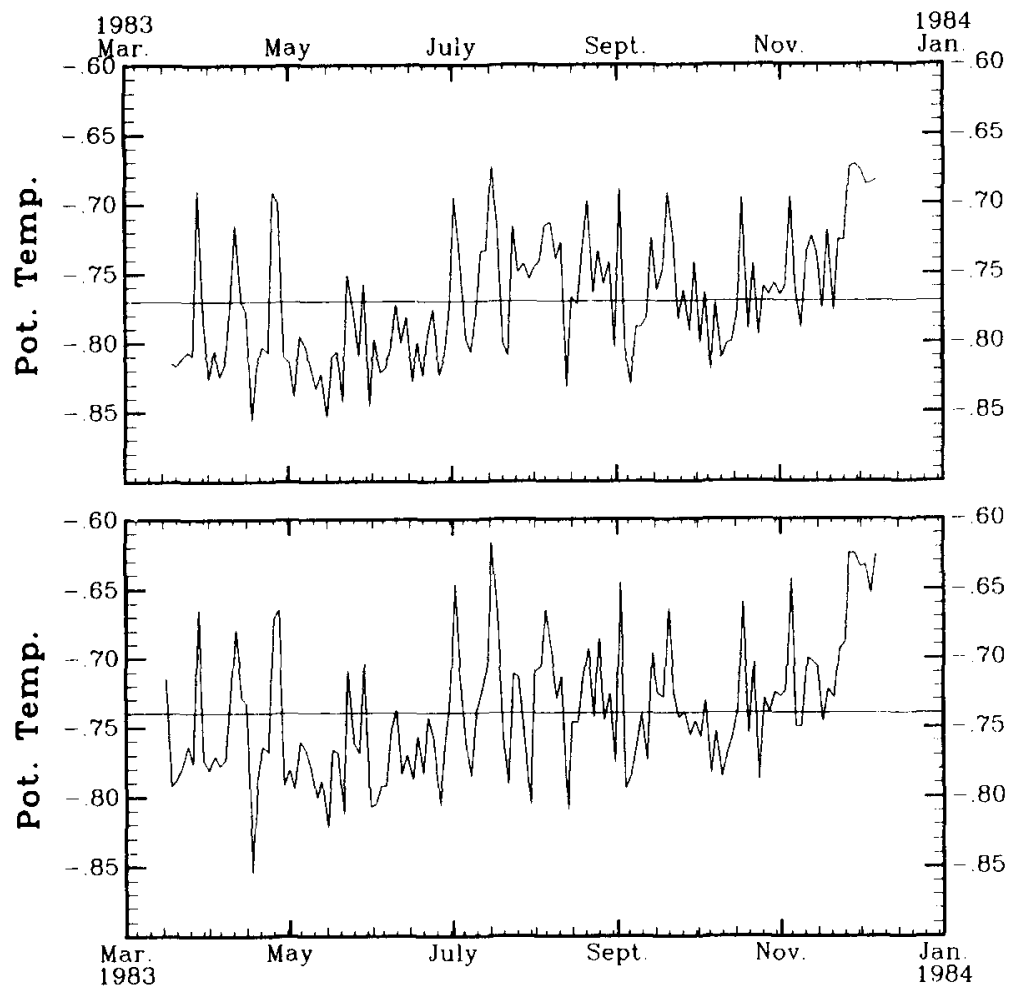

Fig. 17. Potential temperature $\left({ }^{\circ} \mathrm{C}\right.$ ) measured at 1904 (upper panel) and $1964 \mathrm{~m}$ on mooring 289. A 40-h low-pass filter was applied and one value plotted every second day.

As seen, the temperatures from both instruments on mooring 289 were increasing dramatically toward the end of the record, so another possible explanation for the extremely cold temperatures is that the instruments recorded an inflow event from the Powell Basin. This hypothesis is supported by the veering counterflow documented during the last days in December 1983 (Fig. 13). Note (from Fig. 10a) that water colder than $-0.6^{\circ} \mathrm{C}$ was observed on the south side of the ridge only some $300 \mathrm{~m}$ below the nominal mooring depth.

The record-length current statistics, presented graphically in Fig. 18, clearly support several points. (Remember that the record-length mean current at the bottom instrument on each mooring is taken to be the $-u$ direction, so that mean $v$ values at the bottom instruments are zero by definition. Moreover, the $-u$ direction is along isobaths, as well as they can be determined from known bathymetry; this is northwest at 289 and westward at other moorings.) The deep instruments at ST, SS500, 270 and 289 have mean alongisobath components one or more standard deviations removed from zero, indicating relatively persistent currents parallel to bottom contours. At SS1000 the current meter was situated farther above the bottom, perhaps nearer the top of the upper slope current. The mid-depth records on ST and 270 , located north or above the influence of the westward slope current, gave almost zero mean $u$ and $v$ components.

Approximately $61 \mathrm{~km}$ north-northeast of ST was located mooring ML-11 (position shown in Fig. 5), which produced a current record at $2640 \mathrm{~m}$ from January 1979 to 


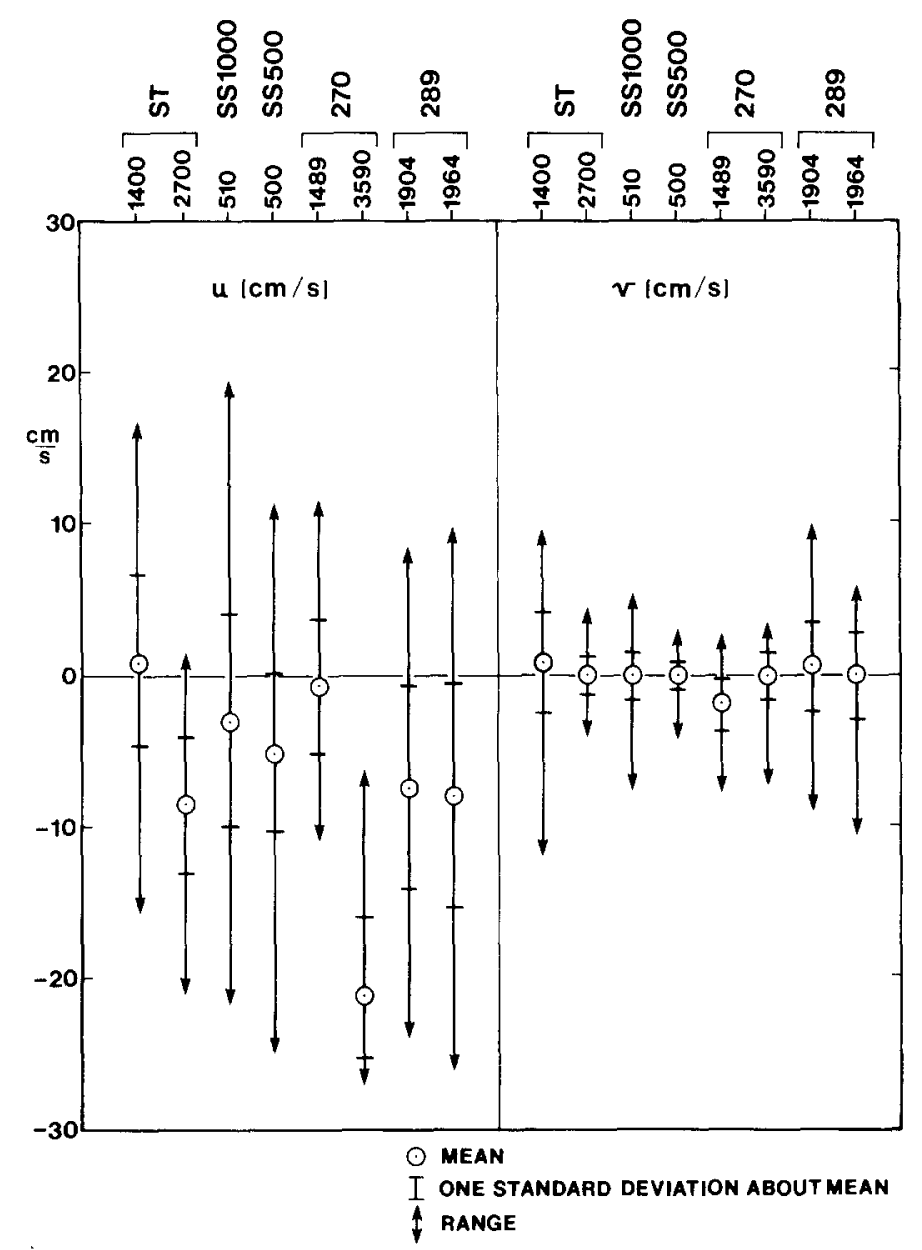

Fig. 18. Comparison of means, standard deviations and ranges for along-isobath $(-u)$ and across-isobath $(v)$ velocity components, based on 40-h low-passed records at indicated moorings and depths.

February 1980 . Flow there was oriented almost due north with a mean speed of $4.7 \mathrm{~cm} \mathrm{~s}^{-1}$ and a standard deviation of only $4.1 \mathrm{~cm} \mathrm{~s}^{-1}$. That flow direction is as expected for the Antarctic Circumpolar Current, which in that location is deflected northward by the Shackleton Fracture Zone ridge. Either the slope current does not extend that far north, or it had no effect because the instrument was $1114 \mathrm{~m}$ above the bottom.

\section{Site-specific analysis}

ISOS moorings at Drake Passage. The westward-flowing current along the continental margin near Livingston Island seems to be confined to the bottom few hundred meters and is directed principally along the isobaths. Cross-correlations of velocity components and of temperature from various instrument pairs are considered first to determine relationships between fluctuations and spatial separation in the most general manner (spanning all frequencies). 
Cross-correlation coefficients $(C)$ were normalized by the large-lag standard error $(S)$ after SCiRemammano (1979). (Values of $C / S$ of $1.7,2.0$ and 2.6 are significantly nonzero at the 90,95 and $99 \%$ levels, respectively.) Presented in Table 3 are $C / S$ values for zero lag and the maximum cross-correlation values with corresponding lag. When no $C / S$ value was found different from zero at the $90 \%$ level, no value for nonzero lag is shown.

Correlations above the $99 \%$ confidence level for each variable occur between the intermediate $(1400 \mathrm{~m})$ and bottom instrument on mooring ST, with lags within 1 day of zero. This is not unexpected; fluctuations in velocity components and temperature are known to be significantly correlated in the vertical through mid-depths at Drake Passage (SCiremammano et al., 1980).

The velocity component fluctuations between SS500 and SS1000 are also significantly correlated (above the $99 \%$ level), as are the temperature fluctuations. The maximum correlation for fluctuations at these meters occurs for little or no lag due to their horizontal proximity. The temperature fluctuations for other pairs of instruments are uncorrelated (below $90 \%$ level); so are the velocity component fluctuations at zero lag, excepting the across-isobath velocity components at SS500 and $1400 \mathrm{~m}$ at ST. The significant maximum cross-correlation of the along-isobath velocity components $(u)$ show a consistent relationship in lag; fluctuations at the shelf-break instruments lead those in

Table 3. C/S at zero lag and maximum value of C/S with lag (in days). Positive lag indicates that the record in the row leads that in the column

\begin{tabular}{llcc}
\hline & \multicolumn{3}{l}{ Cross correlations of $v$ fluctuation } \\
& SS1000 & ST1400 & ST2700 \\
\hline SS500 & 4.41 & 1.99 & 1.33 \\
& $4.41(0)$ & $2.17(-2)$ & $1.99(49)$ \\
SS1000 & & 0.04 & -0.14 \\
& & $-2.19(-23)$ & $-2.35(-27)$ \\
ST1400 & & & 5.03 \\
& & & $5.03(0)$ \\
\hline
\end{tabular}

\begin{tabular}{llll} 
& \multicolumn{2}{c}{ Cross correlations of $u$ fluctuations } & \\
& SS1000 & ST1400 & ST2700 \\
\hline SS500 & 3.26 & 0.76 & 1.57 \\
& $3.75(2)$ & $2.64(18)$ & $2.70(21)$ \\
SS1000 & & -0.39 & 1.46 \\
& & & $2.31(-17)$ \\
ST1400 & & & 3.73 \\
& & & $3.73(0)$ \\
\hline
\end{tabular}

\begin{tabular}{llcc} 
& \multicolumn{2}{c}{ Cross correlations of $T$ fluctuations } \\
& SS1000 & ST1400 & ST2700 \\
\hline SS500 & 2.56 & 0.76 & 0.66 \\
& $2.62(1)$ & & \\
SS1000 & & 0.12 & -0.34 \\
ST1400 & & & 3.23 \\
& & & $3.23(0)$ \\
\hline
\end{tabular}


deeper water by approximately 19 days. The cross-isobath components $(v)$ do not exhibit a consistent pattern.

The coherences (not shown) between velocity component pairs and temperature pairs were examined seeking more definitive phase and frequency relations for the slope current regime at this location. For the ST records the vertically separated velocity components are coherent over a broad range of low frequencies. The $u$ components are significantly coherent (at the $95 \%$ confidence level) for periods greater than 47 days, with the deeper meter leading slightly. Additional significant coherence was observed for a small peak at 18 days and a broader peak extending over periods from 7 to 11 days. The $v$ components are coherent for all periods greater than 20 days with the deeper meter leading somewhat in phase. There are also coherent bands centered at 16 and 11 days for which the upper record leads by 0.6 days and lags by 1.7 days, respectively, those fluctuations at the deep record. Temperature fluctuations between these instruments are coherent and essentially in phase for all periods longer than 12 days.

There is no significant correlation between temperature fluctuations at the moorings on the shelf and upper slope and fluctuations at mooring ST, with the exception of a band at 15-20 days centered near 17 days for which the $510 \mathrm{~m}$ instrument on SS1000 leads that at $1400 \mathrm{~m}$ on ST.

We have compared velocity component fluctuations at the upper shelf instruments on SS500 and SS1000 with those in the westward bottom current at $2700 \mathrm{~m}$ on ST. The crossisobath components were not coherent. Also, fluctuations in the along-isobath component $(u)$ were not coherent between $510 \mathrm{~m}$ on SS1000 and $2700 \mathrm{~m}$ on ST. The pair from SS500 and from $2700 \mathrm{~m}$ on ST showed significant coherence only for isolated frequency bands centered at 11, 15 and 20 days. The fluctuations at SS500 lead those at ST by approximately $42^{\circ}$ for 11 days and $62^{\circ}$ for 20 days but lead by $130^{\circ}$ at 15 days. (If we insist that SS500 lead ST as the cross-correlations imply, by adding a wave period to the phase differences, fluctuations with periods of 15 and 20 days at SS500 lag those at ST by 20 and 18 days, respectively. This is consistent with the cross-correlation lag of 21 days. The smoothing technique used makes the significant coherence estimates near 11 days somewhat dependent on surrounding non-significant values.)

Summarizing the relationships in fluctuations between the bottom current $(2700-\mathrm{m}$ instrument) at mooring ST and those at the upper shelf moorings, we may say that lateral movements ( $v$ fluctuations) and temperature fluctuations in these current regimes are not correlated. Moreover, only for SS500 at a few selected periods (from 15 to 20 days) do the along-isobath fluctuations on the upper slope seem statistically related to those at the base of the slope; for those periods, the shelf fluctuations lead those at depth by about 20 days. This lends additional evidence, together with the observations of distinct water characteristics and differing bottom boundary layer thicknesses, that the upper slope/ shelf current and that along the base of the slope are kinematically distinct.

Mooring 270. At this site northwest of Elephant Island, there is no appreciable coherence for temperature or velocity components between the $3590-\mathrm{m}$ record and that at $1489 \mathrm{~m}$ for short periods which may be examined based on this 49 -day record. Energy levels at the bottom meter were larger by about a factor of 5 than those at the mid-depth meter. It is clear that the bottom meter was in a distinct, and more energetic, current regime.

There have been many reports of current rings in Drake Passage and a few synoptic observations of the formation of such rings from the fronts (current cores) found there. 
Mooring ST was located just south of the front in Drake Passage known as the Continental Water Boundary (WhrTworTH et al., 1982). Based on time series from three depths at a site in the central passage, Pillsbury and Bottero (1984) reported the passage southward of an anticyclonic ring from the Polar Front and northward of five cyclonic rings from the Continental Water Boundary during an 8-month period in 1975/ 1976. We infer the southward passage of an anticyclonic ring from the Continental Water Boundary past mooring 270 based on velocity and temperature records from $1489 \mathrm{~m}$ (Figs 12 and 16).

A ring formed to the poleward side of the Continental Water Boundary would be a warm-core ring. Nowlin and CLIFFORD (1982) have described the thermohaline structure across the Drake Passage fronts. Near $1500 \mathrm{~m}$, they show a temperature difference of several $0.1^{\circ} \mathrm{C}$ across the Continental Water Boundary with the poleward side near or below $1.0^{\circ} \mathrm{C}$. We see a temperature rise of $0.3^{\circ} \mathrm{C}$ from $1.0^{\circ}$ and a subsequent fall in the $1489-\mathrm{m}$ record. During the time of increasing temperature, a maximum in eastward velocity occurred; and a maximum in westward velocity is seen to have accompanied the temperature decrease. This is interpreted as the southward passage of an anticyclonic ring past the mooring. If so, it is the first reported observation of a ring formed south of the Continental Water Boundary and it had drifted eastward since formation. We note that its passage seems to have had no appreciable effect on the deep record at mooring 270 .

Mooring 289. As expected, the instruments on mooring 289 , separated by only $60 \mathrm{~m}$ and close to the bottom, are very coherent in both velocity components. (The coherence between $u$ components is approximately 1 for periods greater than 3 days with zero phase difference. The $v$ components are coherent at well above the $95 \%$ significance level with the exception of one bin near 8 days for which the significance level drops to about $90 \%$.) The temperature series were likewise coherent over the frequency range observed. Surely both instruments were in the same bottom current which must extend at least $85 \mathrm{~m}$ off the sea floor at this location.

The spectral density distributions for the along-isobath components are nearly identical with higher values at the bottom instrument, which may indicate that this current is bottom intensified. The spectra for across-isobath components were a decade lower, and, though not identical, were indistinguishable within $95 \%$ confidence bands. An unexplained observation is a significant energy gap in both of these spectra in the 7-10 days period band.

\section{DISCUSSION AND IMPLICATIONS OF RESULTS}

There is westward near-bottom flow along the South Sandwich Islands in Drake Passage. Weddell Sea Deep Water moves westward along the base of the continental rise, and there is also a westward current over the outer shelf edge and upper slope.

The bottom water in the southern Scotia Sea enters from the Weddell Sea through deep gaps in the Scotia Island Arc, e.g. east of the South Orkney Islands near $40^{\circ} \mathrm{W}$. At depths greater than $3000 \mathrm{~m}$, Weddell Sea Deep Water flows from the southwestern Scotia Sea into Drake Passage through a narrow gap between the ridge of the Shackleton Fracture Zone and the rise of the South Shetland Island Arc. Near-bottom distributions of characteristics show these waters to fill the zonal trough and other deep features north 
of Livingston Island and to continue westward in a narrow tongue along the base of the rise at least as far as $65^{\circ} \mathrm{W}$.

Direct measurements of this westward current along the base of the slope show a high degree of directional persistence oriented along the isobaths. Well-mixed bottom boundary layers of order 500-m thickness are observed. Mean near-bottom speeds may exceed $20 \mathrm{~cm} \mathrm{~s}^{-1}$ in and near the gap in the Shackleton Fracture Zone.

At the sill of the ridge separating the Powell Basin and the Scotia Sea (west of the South Orkney Islands), observations in the $120-\mathrm{m}$ thick, well-mixed bottom boundary show flow from the Weddell Sea of very cold water (in situ temperatures $<-0.5^{\circ} \mathrm{C}$ ) with mean speeds during the 8 -month observation period of nearly $8 \mathrm{~cm} \mathrm{~s}^{-1}$. This is another path for Weddell Sea Deep Water to enter the Scotia Sea at deep mid-depths.

Observations north of Elephant Island in the southwestern Scotia Sea show dense, cold, fresh, oxygenated and very young water over the outer shelf edge. This water extends seaward along the slope to depths of at least $800 \mathrm{~m}$. A thin, though welldeveloped, bottom boundary layer of thickness $50-100 \mathrm{~m}$ is observed at the base of this layer, which extends about one Rossby deformation radius off the shelf edge. North of Livingston Island, this slope current is observed to flow eastward with mean speeds $100 \mathrm{~m}$ above the bottom of about $5 \mathrm{~cm} \mathrm{~s}^{-1}$. The flow is along isobaths and persistent in direction.

These observations of characteristics and stratification are quite similar to those made at several locations over the shelf break around Antarctica. They lead to the hypothesis that this flow along the shelf and upper slope is an extension of the Polar Slope Current around the Antarctic Peninsula, and that even in this northernmost extent of the land mass, local convection is driving a westward flow along the outer shelf and upper slope.

These westward currents probably transport only 1-3 million $\mathrm{m}^{3} \mathrm{~s}^{-1}$ westward, which compared with the net eastward transport through Drake Passage of approximately $135 \times 10^{6} \mathrm{~m}^{3} \mathrm{~s}^{-1}$ is not significant to mass balances at present measurement capabilities. Assuming a $2 \times 10^{6} \mathrm{~m}^{3} \mathrm{~s}^{-1}$ mass transport, we may consider the heat transport by this slope current regime. Relative to $0^{\circ} \mathrm{C}$ the net eastward heat transport through Drake Passage has been estimated as $9.5-13 \times 10^{14} \mathrm{~W}$ (GEORGI and ToOLE, 1982; GiUfFrida, 1985). If the mass-weighted temperature of the westward flow is $-0.2^{\circ} \mathrm{C}$ (which is probably a low estimate, chosen to exaggerate the effect), then the resulting eastward heat transport relative to $0^{\circ} \mathrm{C}$ would be approximately $1.6 \times 10^{12} \mathrm{~W}$, or negligible.

There are important implications for krill biology in these results. Patterns of fish migration are usually considered to be between a spawning area, a nursery area and feeding grounds of the adult stock (JONES, 1968), although in not all cases are these three areas distinct. One result of these migrations is to separate the feeding areas of mature and immature animals- perhaps to provide a better environment for the juveniles, to protect them from the adults or to help ensure enough food for all. For pelagic species such as krill it is recognised that several factors must be considered: the currents, the extent to which eggs and immature larval forms drift with them and animal behavior (Quetin and Ross, 1984a).

Large krill populations have been observed near the South Shetland Islands, and gravid females are regularly obtained in the area. There are indications that schools of different size and maturity are geographically separated (QUETIN and Ross, 1984), but their spawning and adult feeding grounds are not widely separated. After being laid at 
depths of approximately $50 \mathrm{~m}$, krill eggs sink to average depths of $800-1000 \mathrm{~m}$ before hatching (Quetin and Ross, 1984b). Thus, eggs laid north of the South Shetland Islands may be transported westward towards the Bellingshausen Sea by these bottom currents. Rising larval forms then may be transported eastward by surface currents into the region of Bransfield Strait, so that their nursery grounds are effectively along these trajectories.

Acknowledgements - This work was completed during a visit by W. Nowlin to the Institut für Meereskunde an der Universität Kiel. The ISOS data collection was supported by the Ocean Sciences Division of the National Science Foundation which also sponsored the Ajax expedition jointly with the Office of Naval Research. The IfM mooring work from the Meteor and Polarstern was sponsored by the Deutsche Forschungsgemeinschaft. The analyses and publication were supported by the Office of Naval Research. The authors wish to thank K. P. Koltermann and G. Wefer for the deployment and recovery of mooring 289 and $\mathrm{R}$. Weiss and J. Bullister for the use of their fluorocarbon-11 data from the Ajax expedition.

\section{REFERENCES}

ARMi L. and R. C. MillaRd, Jr (1976) The bottom boundary layer of the deep ocean. Journal of Geophysical Research, 81, 4983-4990.

CARMACK E. C. and P. D. Killworth (1978) Formation and interleaving of abyssal water masses off Wilkes Land, Antarctica. Deep-Sea Research, 25, 357-369.

DEACON G. R. E. (1933) A general account of the hydrology of the South Atlantic Ocean. Discovery Reports, 7, 171-238.

Dietrich G., K. Lalle, W. Krauss and G. Siedler (1975) Allgemeine Meereskunde; Eine Einführung in die Ozeanographie. 3. Auflage, Gebruder Borntraeger, Berlin, 593 pp.

Foldvik A., T. Gammelsroed and T. Toerresen (1985) Physical oceanography studies in the Weddell Sea during the Norwegian Antarctic Research Expedition 1978/79. Polar Research, 3, 195-207.

Foster T. D. and E. C. CARMACK (1976) Frontal zone mixing and Antarctic Bottom Water formation in the southern Weddell Sea. Deep-Sea Research, 23, 301-317.

Georgi D. T. and J. M. Toole (1982) The Antarctic Circumpolar Current and the oceanic heat and freshwater budgets. Journal of Marine Research, 40 (Suppl.), 183-197.

Gill A. E. (1973) Circulation and bottom water production in the Weddell Sea. Deep-Sea Research, 20, 111-140.

Gordon A. L. and P. TCHERnia (1972) Waters of the continental margin off Adelie Coast, Antarctica. In: Antarctic oceanology II: The Australian-New Zealand sector, Antarctic Research Series, Vol. 19, D. E. HAYES, editor, AGU, Washington, D.C., pp. 59-69.

Gordon A. L. and E. J. Molinelli (1982) Southern Ocean Atlas (with data tape), Columbia University Press, New York, 11 pp., 233 plates.

GIUFFRIDA M. R. (1985) Estimates of net Antarctic Circumpolar Current transports and Southern Ocean budgets of mass, heat, freshwater, oxygen and silicate. M.S. thesis, Texas A\&M University, 85 pp.

Hollister C. D. and B. C. HeEzen (1967) The floor of the Bellingshausen Sea. In: Deep-sea photography, The John Hopkins Studies, No. 3, Chapter 17, J. B. HerSEY, editor, The John Hopkins Press, Baltimore, MD, pp: $177-189$.

Hollister C. D. and R. B. Elder (1969) Contour currents in the Weddell Sea. Deep-Sea Research, 16, 99-101.

JACOBS S. S. and D. T. GEORGI (1977) Observations of the southwest Indian/Antarctic Ocean. In: $A$ voyage of Discovery, M. ANGEL, editor, Pergamon, New York, pp. 43-84.

Jacobs S. S., A. F. Amos and P. M. BRuCKhausen (1970) Ross Sea oceanography and Antarctic Bottom Water formation. Deep-Sea Research, 17, 935-962.

JONES F. R. H. (1968) Fish migration, Edward Arnold, London, 325 pp.

KILlworth P. D. (1983) Deep convection in the world ocean. Reviews of Geophysics and Space Physics, 21, $1-26$.

Kroenke L. W. and G. P. Woollard (1968) Magnetic investigations in the Labrador and Scotia Seas, U.S. N.S. Eltanin Cruises 1-10, 1962-1963. Hawaii Institute of Geophysics, University of Hawaii, Report HIG$68-4,59 \mathrm{pp}$.

Mantyla A. W. and J. L. Reid (1983) Abyssal characteristics of the World Ocean waters. Deep-Sea Research, 30, 805-833.

Nowlin W. D., Jr and M. Clifford (1982) The kinematic and thermohaline zonation of the Antarctic Circumpolar Current at Drake Passage. Journal of Marine Research, 40 (Suppl.), 481-507.

Pillsbury R. D. and J. S. BotTERo (1984) Observations of current rings in the Antarctic Zone at Drake Passage. Journal of Marine Research, 42, 853-874. 
Pillsbury R. D., J. S. Bottero and R. E. Still (1981) Current, temperature and pressure in the Drake Passage during DRAKE 79, January 1979-January 1980. Data report 91 of School of Oceanography, Oregon State University, Ref. 81-17, 373 pp.

Quetin L. B. and R. M. Ross (1984a) School composition of the Antarctic krill Euphausia superba in the waters west of the Antarctic Peninsula in the austral summer of 1982. Journal of Crustacean Biology, 4 (Special No. 1), 96-106.

Quetin L. B. and R. M. Ross (1984b) Depth distribution of developing Euphausia superba embryos, predicted from sinking rates. Marine Biology, 79, 47-53.

ReID J. L. and W. D. Nowlin, Jr (1971) Transport of water through Drake Passage. Deep-Sea Research, 18, $51-64$.

RohARDT G. (1984) Ozeanographische Untersuchungen. In: Die Expedition Antarktis-II mit FS Polarstern 1983/84, D. Futterer, editor, pp. 51-53. Reports on Polar Research, Vol. 18, Alfred-Wegener-Institute for Polar Research, Bremerhaven, $92 \mathrm{pp}$.

Sciremammano F., Jr (1979) A suggestion for the presentation of correlations and their significance levels. Journal of Physical Oceanography, 9, 1273-1276.

Sciremammano F., Jr, R. D. Pillsbury, W. D. Nowlin, Jr and T. Whitworth III (1980) Spatial scales of temperature and flow in Drake Passage. Journal of Geophysical Research, 85, 4015-4028.

SiEvers H. A. and W. D. Nowlin, Jr (1984) The stratification and water masses in Drake Passage. Journal of Geophysical Research, 83, 10489-10514.

SIO/TAMU (1985) Physical, chemical and in situ CTD data from the AJAX Expedition in the South Atlantic Ocean. Data report issued jointly by Scripps Institution of Oceanography, U.C. San Diego (Ref. 85-24) and Department of Oceanography, Texas A\&M University (Ref. 85-4-D), 275 pp.

Weiss R. F., H. G. Ostlund and H. Craig (1979) Geochemical studies of the Weddell Sea. Deep-Sea Research, 26, 1093-1120.

Weiss R. F., J. L. Bullister, R. H. Gammon and M. J. Warner (1985) Atmospheric chlorofluoromethanes in the deep equatorial Atlantic. Nature, 314, 608-610.

WhITwORTH III, T., W. D. Nowlin, Jr and S. J. Worley (1982) The net transport of the Antarctic Circumpolar Current through Drake Passage. Journal of Physical Oceanography, 12, 960-971.

WITTSTOCK, R.-R. and W. ZENK (1983) Some current observations and surface T/S distribution from the Scotia Sea and the Bransfield Strait during early austral summer 1980/81. Meteor Forschungs-Ergebnisse, Reihe A/B, No. 24, 77-86.

WORLEY S. J. and T. WHITwORTH III (1982) Supplementary data from the DRAKE-79 Experiment: Velocity profiles and time series from temperature/pressure recorders, thermistor chains, conductivity sensors and Geodyne current meters. Data report of the Department of Oceanography, Texas A\&M University, Ref. 82-9-T, $69 \mathrm{pp}$.

ZEITZSCHEL B. and W. ZENK (1981) Beobachtungen und erste Ergebnisse der "Meteor"-Reise 56 aus der Scotia-See und der Bransfield-Strasse im November/Dezember 1980 (ANT I). Berichte Institut für Meereskunde Kiel, 80, 73 pp. 